\title{
Government hesitancy amidst industry discord: Decline of the United States-flag merchant marine after World War II
}

Deborah J. Hennen

West Virginia University

Follow this and additional works at: https://researchrepository.wvu.edu/etd

\section{Recommended Citation}

Hennen, Deborah J., "Government hesitancy amidst industry discord: Decline of the United States-flag merchant marine after World War II" (2006). Graduate Theses, Dissertations, and Problem Reports. 798. https://researchrepository.wvu.edu/etd/798

This Thesis is protected by copyright and/or related rights. It has been brought to you by the The Research Repository @ WVU with permission from the rights-holder(s). You are free to use this Thesis in any way that is permitted by the copyright and related rights legislation that applies to your use. For other uses you must obtain permission from the rights-holder(s) directly, unless additional rights are indicated by a Creative Commons license in the record and/ or on the work itself. This Thesis has been accepted for inclusion in WVU Graduate Theses, Dissertations, and Problem Reports collection by an authorized administrator of The Research Repository @ WVU. For more information, please contact researchrepository@mail.wvu.edu. 


\title{
Government Hesitancy amidst Industry Discord: Decline of the United States-Flag
} Merchant Marine after World War II

\author{
Deborah J. Hennen
}

\author{
Thesis submitted to the \\ Eberly College of Arts \& Sciences \\ at West Virginia University \\ in partial fulfillment of the requirements \\ for the degree of
}

\section{Master of Arts}

in

History
A. Michal McMahon, Ph.D., Chair
Jason Parker, Ph.D.
Kenneth Fones-Wolf, Ph.D.

Department of History
Morgantown, West Virginia
2006

Keywords: Merchant Marine, American-Flag Shipping, Maritime Industry Copyright 2006 Deborah J. Hennen 


\begin{abstract}
Government Hesitancy amidst Industry Discord: Decline of the United States Flag Merchant Marine after World War II
\end{abstract}

Deborah J. Hennen

The American-flag merchant marine became the world's largest during World War II. U.S.-flag ships carried most of the nation's commerce, and the world looked to America for shipping strength. After the war, the different parties in the maritime industry began to fight for their individual interests as the American standard of living became the highest in the world. The federal government hesitated to step in and calm the growing discord, and several decades passed as American maritime policy stagnated. Only after the parties in the industry began cooperating with each other did Congress take positive steps to aid the American-flag merchant marine, but it still hesitated when industry disagreement or American foreign policy concerns surfaced. Since the U.S. government today remains ambivalent toward its national merchant fleet, cooperation by the parties comprising the maritime industry will be the only road toward recovery of a strong American-flag merchant marine. 


\section{Acknowledgements}

I would like to thank the professors in the History Department at WVU for their encouragement and support as I entered a new field of study. I am especially grateful to Dr. Michal McMahon for pushing me to think like a historian and for helping me to develop writing skills that made my work more coherent and understandable. Also, thank you to Dr. Jason Parker for pointing me in the right direction to begin this project and to Dr. Ken Fones-Wolf for his patient assistance.

I am also indebted to my colleagues, shipmates, and friends in the maritime industry both ashore and at sea. Without them, I would not have been able to advance my career beyond my first days as a cadet.

I owe a very special thank you to the Department of History Graduate Committee for bestowing on me the honor of the Regina Hale Canaga Memorial Scholarship for the 2005-2006 academic year. Without that generous award, I would have been unable to finish my studies without interruption.

And finally, to my family: thank you for always providing me with a home to return to after countless months of sailing the seas. 


\section{Table of Contents}

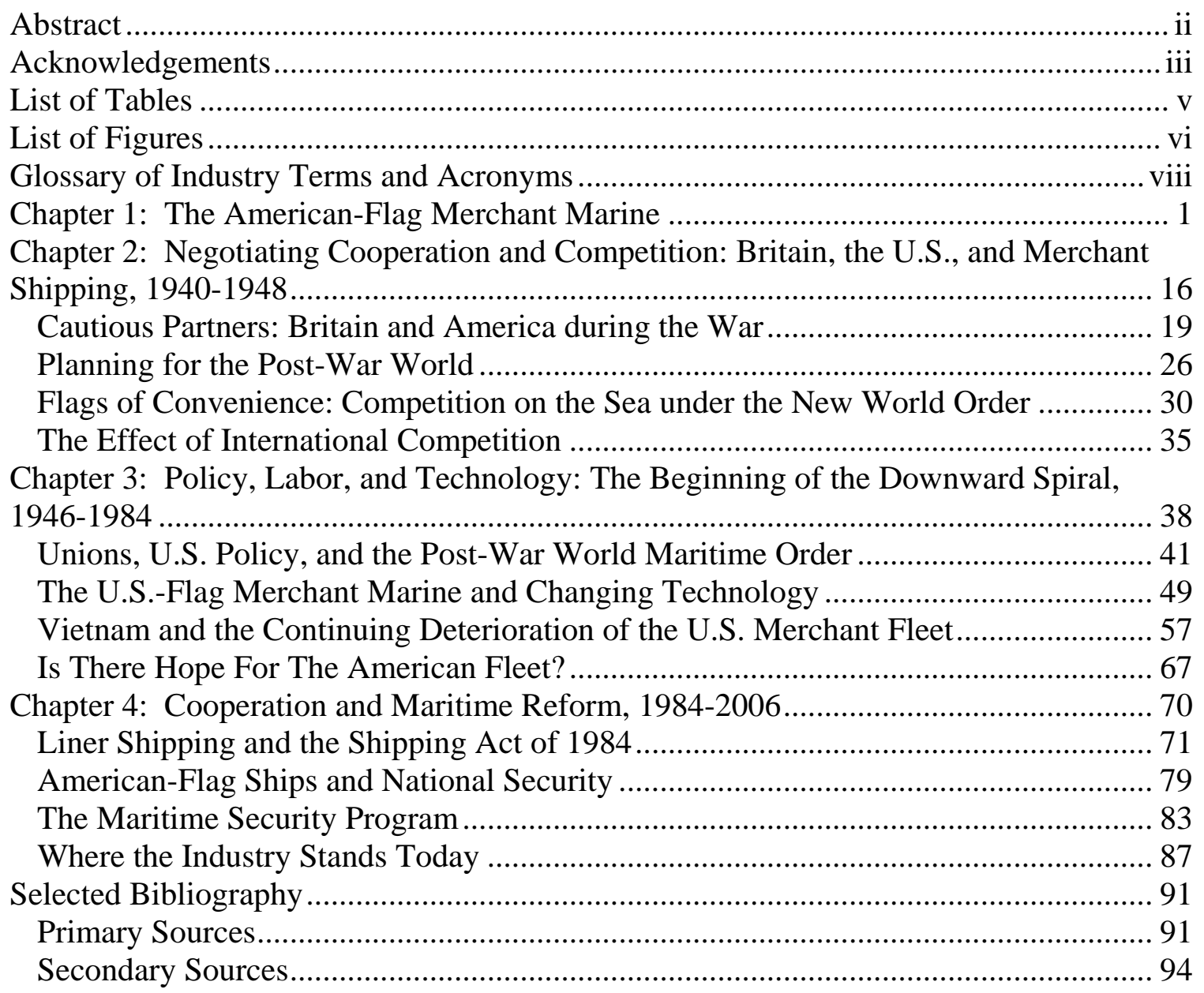




\section{List of Tables}

Table I. Top 20 Merchant Fleets of the World; Self-Propelled

Oceangoing Vessels 1,000 Gross Tons and Greater; As of July, 1, 2004;

available from

http://www.marad.dot.gov/MARAD_statistics/Flag-MFW-7-04.pdf;

Internet: accessed on 20 June 2006.

Table II. Rise \& Decline of the Merchant Marine 1939-2003;

U.S. Department of Commerce, Bureau of the Census, Statistical Abstracts of the United States, for years 1939-2005;

and "U.S.-Flag Merchant Fleet," available from http://www.marad.dot.gov/MARAD_statistics/US-FLAG-HISTORY.pdf; Internet: accessed on 20 June 2006 when information not available from Statistical Abstracts.................................................14 


\section{List of Figures}

Figure 1. Liberty ship, SS Anson Jones, underway. A. A. Hoehling, The Fighting Liberty Ships: A Memoir (Annapolis: Naval Institute Press, 1996), Cover.

Figure 2. Victory ship underway. Christopher Batio, Super Cargo Ships (Osceola: MBI Publishing Company, 2001), 17. 26

Figure 3. Schenectady in 1943 moored in its dock after sea trials, available from http://www.fiu.edu/ thompsop/liberty/photos/schenectady.jpg; Internet: accessed on 02 May 2006.

Figure 4. Malcolm McLean's first containership, Ideal $X$, available from http://www.portofhouston.com/pdf/pubaffairs/PHA90th\%20History\%20Brochure.pdf\#search='ideal\%20x\%20ship'; Internet: accessed on 17 May 2006. 54

Figure 5. The United States' only nuclear-powered merchant ship, the NS Savannah. Christopher Batio, Super Cargo Ships (Osceola: MBI Publishing Company, 2001), 83. 55

Figure 6. San Clemente Class supertanker underway. “Commercial Ship Portfolio: San Clemente Class Tanker,” available from http://www.nassco.com/cdc/cportfolio/sanclem_enlg.html; Internet: accessed on 08 March 2006. 60

Figure 7. Marine Electric underway, available from

http://www.northernatlanticdive.com/2004_expeditions/marine_electric.jpg;

Internet: accessed on 22 June 2006.

Figure 8. Maersk Virginia, formerly named Maersk Geelong, was built in 2002 and reflagged from the Singapore registry to the American flag to become part of the Maritime Security Program; it is one of the most modern containerships in the American-flag fleet today, available from http://about.maersk.com/en/Fleet/Container/ContainerPanamax/SeriesDG/Maersk

Virginia.htm; and http://www.globalsecurity.org/military/systems/ship/maersk-g.htm; Internet: accessed on 22 June 2006. 72

Figure 9. Freedom, formerly named Takamine, was reflagged under the American registry to participate in the Maritime Security Program. "New AMO jobs on U.S.-flagged car carrier," American Maritime Officer, October 2003, 1. 
Figure 10. USNS Bob Hope, one of the MSC surge sealift LMSRs, available from http://www.msc.navy.mil/inventory/ships.asp?ship=104\&type=LMSR;

Internet: accessed on 22 June 2006.

Figure 11. Sea-Land Florida, originally named American New York, was one of Malcolm McLeans twelve "Econships” built in the 1980s, available from http://www.maerskline.com/link/?page=brochure\&path=/about_us/photo_gallery/ vessels_at_sea/Sealand_Florida_gallery; Internet: accessed on 22 June 2006. 78

Figure 12. USNS Algol, one of eight fast sealift ships used by MSC for surge sealift campaigns, available from http://www.msc.navy.mil/inventory/ships.asp?ship=algol\&type=FastSealiftShip; Internet: accessed on 22 June 2006. 


\section{Glossary of Industry Terms and Acronyms}

ABS - American Bureau of Shipping (Ship classification society)

AMO - American Maritime Officers (Maritime union)

APL - American President Lines (Liner shipping company)

ARA - American Radio Association (Maritime Union)

Bulk Cargo - “A homogeneous mass of unpackaged goods, such as coal, ore, grain, oil, or sand.” W. A. McEwen and A. H. Lewis, Encyclopedia of Nautical Knowledge (Centreville: Cornell Maritime Press, 1953), 72.

Deferred Rebate - Under the Shipping Act of 1916 a deferred rebate is "a return of any portion of the freight money by a carrier to any shipper as a consideration for the giving of all or any portion of his shipments to the same or any other carrier, or for any other purpose, the payment of which is deferred beyond the completion of the service for which it is paid, and is made only if, during both the period for which computed and the period of deferment, the shipper has complied with the terms of the rebate agreement or arrangement." U.S. Congress, $64^{\text {th }}$ Cong., $1^{\text {st }}$ sess., Chapter 451, Shipping Act of 1916, 07 September 1916, Sec. 14(1).

Fighting Ship - Under the Shipping Act of 1916 a fighting ship is “a vessel used in a particular trade by a carrier or group of carriers for the purpose of excluding, preventing, or reducing competition by driving another carrier out of said trade.” Shipping Act of 1916, Sec. 14(1).

Flag of Convenience (FOC) - "Practice of registering a merchant vessel with a country that has favorable (i.e. less restrictive) safety requirements, registrations fees, etc." Henry Campbell Black, Black's Law Dictionary: Definitions of the Terms and Phrases of American and English Jurisprudence, American and English Jurisprudence, Ancient and Modern (St. Paul: West Publishing Co., 1979), 574.

Hove to - “To bring one’s vessel to a stop, as required for some special purpose, an emergency, etc.” Encyclopedia of Nautical Knowledge, 227.

ICC - Interstate Commerce Commission

ILWU - International Longshoremen and Warehousemen’s Union (Dock workers union)

ITF - International Transport Workers Federation (International union for transportation labor)

Knot - One nautical mile per hour. Encyclopedia of Nautical Knowledge, 271. 
List - The leaning of a ship to port or starboard caused by an unequal distribution of weight on board. Encyclopedia of Nautical Knowledge, 300.

LMSR - Large Medium Speed Ro/Ro

MARAD - Maritime Administration (Division of the Department of Transportation that specializes in maritime matters)

MEBA - Marine Engineers’ Beneficial Association (Maritime union)

MMP - International Organization of Masters, Mates, and Pilots (Maritime union)

MPF - Maritime Prepositioning Force

MSP - Maritime Security Program (Legislation)

MSC - Military Sealift Command

NDRF - National Defense Reserve Fleet

NMU - National Maritime Union (Maritime union)

NLRB - National Labor Relations Board

Ro/ro - Roll on/roll off ship; a ship where the majority of the cargo is driven on and off the ship by way of cargo ramps; specialized ship used mainly for the transportation of vehicles. René de la Pedraja, A Historical Dictionary of the U.S. Merchant Marine and Shipping Industry Since the Introduction of Steam (Westport: Greenwood Press, 1994), 508-509.

RRF - Ready Reserve Fleet

SIU - Seafarers’ International Union (Maritime union)

SOA - Staff Officers’ Association (Maritime union)

SUP - Sailors' Union of the Pacific (Maritime union)

Surge Sealift - Term used by the military to refer to the initial cargo needed for a military campaign that must reach the operation area quickly. "Military Sealift Command; Sealift Program; Surge Project Office;” available from http://www.msc.navy.mil/pm5/default.asp?page=surge; Internet: accessed 29 June 2006. 


\section{Chapter 1: The American-Flag Merchant Marine}

The American-flag merchant ship Marine Electric carried bulk cargos along the east coast of the United States. It was constructed of the bow and stern sections of a T-2 tanker built in 1944. It was fitted with a midsection built in 1962. In the early 1980s, the Marine Electric was carrying coal along the East Coast of the United States. The ship departed Norfolk, Virginia early on the morning of February 11, 1983 and began its final voyage northbound with a load of coal bound for Brayton Point, Massachusetts. The weather forecast announced winds of 25-35 knots for the outbound trip, but the ship had endured similar weather before with little problem.

Early on the morning of February 12, 1983, the off-duty crew of the Marine Electric was awakened and told to muster with their lifejackets at the starboard lifeboat. The captain, mate on watch, and helmsman began to notice that the ship’s bow was settling lower in the water as the ship progressed up the coast. The Marine Electric was taking on water at the bow and was sinking. A gale blew and temperatures neared freezing. The ship began to list about $10^{\circ}$ to starboard, but the starboard lifeboat could still be launched if necessary. After everyone was prepared, but before the captain had a chance to give the order to abandon ship, the Marine Electric took one final roll to starboard and pitched the crew waiting by the lifeboat into the water. The ship then capsized, trapping the remaining crew on board. The crewmen in the water faced the gale and freezing temperatures until the U.S. Coast Guard and other ships in the area could reach them. When the rescuers arrived, only three men were still alive. In all, the rescuers recovered three survivors and 24 bodies of the crew of the Marine Electric. 
Seven crewmen were never found, including the captain and several engineers who may have been trapped below deck when the ship capsized. ${ }^{1}$

The Marine Electric incident is a telling example of the demise of the U.S.-flag merchant fleet after World War II. Ships built in a hurry to fulfill wartime needs were sold to commercial interests and operated well past their intended and useful lives. Shipowners were motivated to keep the American flag flying on their ships by preference cargoes that were very profitable and were only allowed by law to be carried by U.S.-flag ships. In order to operate on domestic trade routes or to carry government-sponsored cargoes, the law not only required that the ship be registered in the United States, but that it be American built. Although business interests did develop and build new ships to meet the needs of a changing world, the old ships were kept operating in order to save money and increase profits.

The American-flag merchant marine developed throughout the twentieth century under several complex subsidy systems. The U.S. government had supported its merchant marine with direct and indirect subsidies since the formation of the United States as a sovereign nation. Of the indirect subsidies, one of the most restrictive has been in effect in some form since 1789, requiring that ships registered under the American flag be built in the United States. Today, this law is one of the most protective measures employed in retaining an American flag coastwise fleet and is embodied in the Merchant Marine Act of 1920, more commonly known as the Jones Act. ${ }^{2}$ Since this

1 U.S. Department of Transportation, U.S. Coast Guard, Marine Casualty Report, SS Marine Electric, O.N. 245675, Capsizing and Sinking in the Atlantic Ocean on 12 February 1983 with Multiple Loss of Life. U.S. Coast Guard Marine Board of Investigation Report and Commandant's Action, 25 July 1984.

2 U. S. Department of Transportation, Maritime Administration. Compilation of Maritime Laws (Washington, D.C.: U.S. Government Printing Office, 2005), 307-311; 46 USC App. 877 (2004). 
paper deals mainly with the interactions of the American-flag merchant marine in international trade, a comprehensive study of the implications of the Jones Act on the American-flag fleet is not addressed here. However, the linkage of American ship registry to the American shipbuilding industry was an important factor not only under the Jones Act for domestic trade, but also for development of an international American fleet. In the early twentieth century, for a shipowner to register a ship under the American flag, law required him to build the ship in the United States. In addition, the government offered monetary promotional programs to American ships. For example, the Merchant Marine Act of 1928 provided for mail subsidies to shipowners. Corruption and mismanagement of subsidy money led to big corporate profits, but not to a viable American-flag merchant marine. ${ }^{3}$

In an attempt to continue aid to the American merchant marine but to correct the flaws of the Merchant Marine Act of 1928, in 1936, President Franklin Roosevelt signed into law a revised Merchant Marine Act. To today, the policy embodied in this act has remained substantially the same. ${ }^{4}$ The 1936 act promoted subsidies to the maritime

${ }^{3}$ René De La Pedraja, The Rise and Decline of U. S. Merchant Shipping in the Twentieth Century (New York: Twayne Publishers, 1992), 111.

${ }^{4}$ Title I-Declaration of Policy of the Merchant Marine Act of 1936 reads as follows:

SEC. 101. FOSTERING DEVELOPMENT AND MAINTENANCE OF MERCHANT MARINE. It is necessary for the national defense and development of its foreign and domestic commerce that the United States shall have a merchant marine (a) sufficient to carry its domestic water-borne commerce and a substantial portion of the water-borne export and import foreign commerce of the United States and to provide shipping service on all routes (deleted by Merchant Marine Act of 1970) essential for maintaining the flow of such domestic and foreign water-borne commerce at all times, (b) capable of serving as a naval and military auxiliary in time of war or national emergency, (c) owned and operated under the United States flag by citizens of the United States insofar as may be practicable, (d) composed of the bestequipped, safest, and most suitable types of vessels, constructed in the United States and manned with a trained and efficient citizen personnel, and (e) supplemented by efficient facilities for shipbuilding and ship repair (added by Merchant Marine Act of 1970). It is hereby declared to be the policy of the United States to foster the development and encourage the maintenance of such a merchant marine. Compilation of Maritime Laws, 1; 46 U.S.C. App. 1101 (2004); U.S. Congress, $74^{\text {th }}$ Cong., $2^{\text {nd }}$ sess., Ch. 858, Merchant Marine Act of 1936, Title I, Sec. 101, 29 June 1936. (Italics indicates changes that were made by the Merchant Marine Act of 1970.) 
industry, while attempting to administer them more evenly than had the 1928 act by constructing new ships that could compete with foreign shipping interests. The 1936 act also made allowance for subsidy money to compensate for higher operating costs incurred by shipowners, including higher labor costs of employing American officers and seamen.

At the turn of the twentieth century, shipowners and their associates often exploited merchant seamen. Shipowners hired shipping agents to find seamen to man their ships. These agents cheated many seamen out of their wages by overcharging them for room and board in boarding houses ashore, which in turn caused seamen to be indebted to them. A vicious cycle of exploitation for profit developed since the seamen would then be required to ship out just to pay the agents. Aboard ship, living quarters were small, overcrowded, and unsanitary. The food was often of the poorest quality and rotten. $^{5}$

Prior to the passage of the LaFollette Seamen’s Act of 1915, shipowners were required to hire American officers, but could employ unlicensed seamen from anywhere in the world. American officers received higher wages than those of other nationalities, and seamen employed on board American-flag ships were also paid higher wages than on the ships of other nations even though they were not American citizens. ${ }^{6}$ The LaFollette Seamen’s Act required owners, in addition to hiring American officers, to employ seamen of which at least $75 \%$ were fluent in English. ${ }^{7}$ Higher wages resulted, prompting

${ }^{5}$ Bruce Nelson, Workers on the Waterfront: Seamen, Longshoremen, and Unionism in the 1930s (Urbana: University of Illinois Press, 1990), 11-18.

6 Paul Maxwell Zeis, American Shipping Policy (Princeton: Princeton University Press, 1938), 46.

7 De La Pedraja, Rise and Decline of U. S. Merchant Shipping, 16. 
shipowners to seek government subsidies in order to allow them to compete for profit in the foreign trades.

The LaFollette Seamen's Act began a surge of labor activism in the maritime industry that peaked in the 1930s. Longshoremen and seamen organized into unions and attempted to gain a better standard of living and working environment. They fought to end shipping agent abuses and to better the conditions aboard ship. Leaders in the maritime industry began to organize both shipboard and shoreside workers, resulting in the formation of several different maritime unions. Leaders who were instrumental to this organizing effort were Harry Bridges and Harry Lundeberg.

Harry Bridges, an Australian, was raised in a middle class English family. Later, as he traveled the world as a seaman, Bridges developed a feeling that "there was something wrong with the system," especially as he encountered poor conditions in ports around the world. ${ }^{8}$ Combined with his involvement in the Australian labor movement, this experience led him later to affiliate with radical unions such as the Industrial Workers of the World (IWW) and eventually with the Communist party, even though Bridges always maintained that he was not a member. ${ }^{9}$ Bridges' acceptance of Communist ideologies placed him at odds with another major leader in maritime unionization, Harry Lundeberg. This split between the different labor unions led to many years of dispute that added to disruption in the industry.

Maritime unions gained ground by using the strike as a major tool, but during World War II, seamen, in support of the war effort, agreed to a no-strike policy. They were also subject to the War Labor Board's regulations pertaining to wages for the

\footnotetext{
${ }^{8}$ Nelson, Workers on the Waterfront, 26-27.

9 Nelson, Workers on the Waterfront, 60, 66, 145, 263-266.
} 
duration of the war. War policies such as extra pay for ship operations in a war zone kept the wages of seamen higher than during peacetime. After the war, when these bonuses were eliminated, the seamen again began to bargain collectively, but in separate groups embracing different ideologies. Consequently wages rose, making ship operation more expensive on American-flag ships. ${ }^{10}$

The United States had emerged from World War II as one of the strongest nations in the world. Europe had been decimated by the war, and the United States took charge in the European recovery effort. World War II was not only a conflict between the Allied and Axis powers. World economic competition did not cease due to the exigencies of war. The United States and Great Britain, though allies in war, remained economic competitors throughout the conflict.

At the end of World War II, the United States led the world in merchant shipping. The U.S. built Liberty ships and T-2 tankers in such large quantities to win the Battle of the Atlantic and aid the Allied victory that many ships remained at the end of hostilities. Even though these ships were built poorly and had difficulty even when new, it was imperative to the war effort for ship production to continue on a large scale. Despite knowing that the ships had structural problems, the United States government sold many of them to commercial interests after the war in order to put the merchant marine back into private hands from almost total government operation. War-built ships were modified and refitted with new cargo sections and continued to operate in American trade into the 1980s. The Marine Electric was one of these ships.

\footnotetext{
10 U. S. Congress, House, Committee on Merchant Marine and Fisheries, Labor-Management Problems of the American Merchant Marine, 84 ${ }^{\text {th }}$ Cong., $1^{\text {st }}$ sess., 11 July 1955, 444.
} 
In the post-war world shaped by economic competition between nations, costs became the main concern of shipowners. As maritime unions gained better conditions and wages for seamen, American shipowners turned from the American flag and sought lower operating costs through open ship registries that came to be known as flags of convenience. Under a flag of convenience registry, a shipowner paid lower taxes, faced less regulatory restriction, and could choose labor from anywhere in the world. The American government supported the advancement and continued use of flags of convenience in the world market. U.S. political leaders like former Secretary of Commerce W. Averell Harriman and former Secretary of State Edward R. Stettinius actively patronized and/or developed flag of convenience registries.

On board flag of convenience ships, foreign seamen shipped out just as American seamen had over a century ago: under shipping agents. Like the shipping agents used by American shipowners in the early twentieth century, foreign shipping agents linked to flag of convenience ships took advantage of the foreign seamen whose interests they were hired to protect. Shipowners would abandon their ships without paying the crew, and shipping agents would take fees for jobs that didn’t exist, sending seamen to foreign ports at their own expense when no job was forthcoming. ${ }^{11}$ Seamen on board many flag of convenience ships were also not provided with necessary safety and lifesaving equipment comparable to that which was required by law on board an American-flag ship. $^{12}$

${ }^{11}$ Paul K. Chapman, Trouble on Board: The Plight of International Seafarers (Ithaca: ILR Press, 1992), 22-23, 30-31.

12 See William Langewiesche, The Outlaw Sea: A World of Freedom, Chaos, and Crime (New York: North Point Press, 2004), 8-31. 
Flag of convenience registries not only hurt American-flag shipping, but also attracted ships away from many of the European countries that had strong maritime traditions. Some of these countries tried to keep their shipowners from fleeing their national flags by adopting international registries. This type of registry, similar to the open registry, relaxed many of the regulations for documenting a ship. Choice of labor, lower taxation, and reduced registration fees were offered to tempt shipowners who had already shifted to flag of convenience registries back to their home nations. Norway, Denmark, Germany, and France offered international registries for ships flying their national flags. ${ }^{13}$ Nevertheless, open registries continued to spread. (See Table I.)

In addition to the challenge presented to the American-flag fleet by foreign competition, technological advances in cargo handling and methods of propulsion also changed the industry. The introduction of containerization by Malcolm McLean led to bigger ships that required fewer workers. In the engine room, automation and more efficient engines eliminated other workers. But even as technology advanced in the American maritime industry, the older World War II-era ships still operated in commercial trade. The subsidy scheme of the Merchant Marine Act of 1936 no longer provided the needed assistance to upgrade the entire American-flag fleet. The 1936 act was amended in 1970, but still fell short of revitalizing the industry.

As the American-flag fleet shrunk in the 1980s when many wartime ships were finally scrapped, the parties in the industry began to be more understanding of each

13 N. Shashikumar, “Comparative Maritime Policies: A U.S. Dilemma,” Transportation Journal, 34, no. 1 (Fall 1994): 34; N. Shashikumar, "World Shipping Competition,” in William A. Lovett, United States Shipping Policies and the World Market (Westport: Quorum Books, 1996), 93-95. 
other's concerns. Once they began to cooperate amongst themselves and with each other, Congress responded with new programs to boost the American-flag merchant marine.

Historiography on the decline of the American-flag merchant marine is as extensive and complicated as the maritime industry itself. Many works are very broad in the time periods they study, such as A Maritime History of the United States: The Role of America's Seas and Waterways where Jack Bauer only dedicates a few short chapters to post-World War II study; and Sailing on Friday: The Perilous Voyage of America's Merchant Marine by John A. Butler who begins in colonial times and, like Bauer, only devotes a few chapters to post-war maritime activity. ${ }^{14}$ Wide overviews of the entire industry from before its inception as a national entity, while important to the greater body of maritime history, lend little to pinpoint why the merchant fleet has declined to its present state. The Abandoned Ocean: A History of United States Maritime Policy by Andrew Gibson, a former Maritime Administrator under Richard Nixon, and Arthur Donovan, a professor at the U.S. Merchant Marine Academy, contains more policy suggestion than analysis of what happened to the U.S.-flag merchant fleet. Gibson and Donovan suggest that U.S. maritime policy was not adequate to maintain a viable American-flag merchant fleet because it was premised on the wrong assumptions, then they proceed with ideas on how to repair what they deem faulty policy. Gibson and Donovan present a broad overview of maritime history since they also begin their examination in colonial times. While their post-war study is more substantial than both

14 See K. Jack Bauer, A Maritime History of the United States: The Role of America's Seas and Waterways (Columbia: University of South Carolina Press, 1988); and see John A. Butler, Sailing on Friday: The Perilous Voyage of America's Merchant Marine (Washington: Brasswy’s, 1997). 
Bauer's and Butler's, they present more policy than history. ${ }^{15}$ René de la Pedraja and Rodney Carlisle study the industry from more narrow perspectives. De la Pedraja provides a comprehensive study of the successes and failures of American shipping companies in The Rise \& Decline of U.S. Merchant Shipping in the Twentieth Century. He tells the story of American-flag shipping by examining the interaction of shipping companies with each other and the destruction of American-flag shipping companies through bad business decisions. ${ }^{16}$ Flags of convenience and the related doctrine of effective control are explained and analyzed by Rodney Carlisle in Sovereignty for Sale: the Origins and Evolution of the Panamanian and Liberian Flags of Convenience. Carlisle details the origins and uses of flags of convenience, and gives insight to why shipowners and the American government supported such enterprises and how they affected American-flag ships. ${ }^{17}$

Since the study of the decline of the American-flag merchant marine is such a complex topic, this paper concentrates on the period of its greatest height through its steady regression until today. Unlike De la Pedraja and Carlisle who study isolated parts of the maritime industry, the decline of the American-flag merchant marine is here examined through the interaction of the several parties which form the industry. No solutions are presented here, only an attempt to answer the question of how the strongest merchant fleet in the world in a short period of time declined into obscurity.

15 See Andrew Gibson and Arthur Donovan, The Abandoned Ocean: A History of United States Maritime Policy (Columbia: University of South Carolina Press, 2000).

16 See De la Pedraja, Rise \& Decline of U.S. Merchant Shipping.

17 See Rodney Carlisle, Sovereignty for Sale: The Origins and Evolution of the Panamanian and Liberian Flags of Convenience (Annapolis: Naval Institute Press, 1981). 
The American maritime industry has progressed as a complex system involving many different parties with conflicting interests. In addition to these many parties, economics, national security, and technology also affected the condition of the industry. The many people and aspects involved in making the maritime industry work made it easy for the parties to blame each other when times were bad. Continuous bickering led to long periods of stagnation in the American maritime industry. The U.S. government hesitated to act in the hostile environment created by shipowners, shippers, shipyards, and labor fighting to get the upper hand. Consequently, little was done in the United States as foreign competition moved forward.

Much of the U.S. government's merchant marine policy was grounded in legislative acts that were established in the early twentieth century. The United States government retained a definite policy toward maintaining a national merchant fleet since the enactment of the Merchant Marine Act of 1936.

Technological advances in engine automation, more efficient cargo handling and shipboard equipment, and the higher cost of American seamen contributed to the decline of the U.S.-flag merchant fleet in worldwide competition. However, the major factor causing the decline of the U.S.-flag merchant fleet was the failure of the many diverse parties in the industry to unite in a timely manner to stop the deterioration of the American-flag fleet. Ineffective oversight by the U.S. government of subsidy programs combined with government inattention to changing problems in the American fleet, including management-labor conflicts, aging ships, and stagnant maritime policy, fueled the enmity between and among the different factions of the industry. Without cooperation among the members of the maritime community, the merchant marine policy 
of the United States was reduced to the rhetoric stated in the Merchant Marine Act of 1936. 
Table I - Top 20 Merchant Fleets of the World

Self-Propelled Oceangoing Vessels 1,000 Gross Tons and Greater

As of July, 1, 2004

\begin{tabular}{|c|c|c|c|}
\hline & Flag of Registry & Number of Ships & Deadweight Tons \\
\hline 1 & Panama* & 4822 & $187,164,000$ \\
\hline 2 & Liberia* & 1477 & $81,821,000$ \\
\hline 3 & Greece & 730 & $54,442,000$ \\
\hline 4 & Bahamas* & 979 & $43.513,000$ \\
\hline 5 & Hong Kong* & 733 & $38,844,000$ \\
\hline 6 & Malta* & 1172 & $38,798,000$ \\
\hline 7 & Singapore & 886 & $36,843,000$ \\
\hline 8 & Cyprus & 975 & $34,285,000$ \\
\hline 9 & Marshall Islands* & 456 & $33,269,000$ \\
\hline 10 & China & 1557 & $26,490,000$ \\
\hline 11 & Norway (NIS)* & 575 & $23,207,000$ \\
\hline 12 & United States & 412 & $13,035,000$ \\
\hline 13 & Japan & 555 & $11,871,000$ \\
\hline 14 & India & 286 & $11,363,000$ \\
\hline 15 & Isle of Man* & 246 & $10,604,000$ \\
\hline 16 & United Kingdom & 378 & $10,369,000$ \\
\hline 17 & Italy & 438 & $10,197,000$ \\
\hline 18 & Korea (South) & 530 & $9,861,000$ \\
\hline 19 & Denmark (DIS)** & 244 & $9,034,000$ \\
\hline 20 & Iran & 123 & $8,827,000$ \\
\hline
\end{tabular}

* Open Registries

** International Ship Registries

NIS - Norway International Shipping Registry

DIS - Denmark International Shipping Registry

Source: http://www.marad.dot.gov/MARAD_statistics/Flag-MFW-7-04.pdf; Internet: accessed on 20 June 2006. 
Table II - Rise \& Decline of the Merchant Marine 1939-2003

Self-Propelled Oceangoing Vessels 1,000 Gross Tons and Greater

Private and Government-owned American-Flag Ships

\begin{tabular}{|c|c|c|c|c|c|}
\hline & No. of Ships & $\begin{array}{c}\text { Deadweight } \\
\text { Tons }\end{array}$ & $\begin{array}{c}\text { \% of U.S. } \\
\text { Imports } \\
\text { Carried by } \\
\text { American- } \\
\text { Flag Ships }\end{array}$ & $\begin{array}{c}\text { \% of U.S. } \\
\text { Exports } \\
\text { Carried by } \\
\text { American- } \\
\text { Flag Ships }\end{array}$ & $\begin{array}{c}\text { Average } \\
\text { Monthly } \\
\text { Employment } \\
\text { of Seafarers }\end{array}$ \\
\hline 1939 & 1398 & $11,699,000$ & 29.6 & 17.1 & 52,445 \\
\hline 1940 & 1300 & $11,019,000$ & 38.8 & 21.2 & 50,975 \\
\hline 1941 & 1168 & $10,096,000$ & N/A & N/A & 50,225 \\
\hline 1942 & N/A & N/A & 63.5 & 38.9 & 47,650 \\
\hline 1943 & N/A & N/A & 79.8 & 53.0 & 76,800 \\
\hline 1944 & N/A & N/A & 78.7 & 61.6 & 125,755 \\
\hline 1945 & N/A & N/A & 79.7 & 61.2 & 158,755 \\
\hline 1946 & 4852 & $50,263,000$ & 65.8 & 57.2 & 120,050 \\
\hline 1948 & 3490 & $36,774,000$ & 60.1 & 39.1 & 80,250 \\
\hline 1950 & 3408 & $36,526,000$ & 43.7 & 32.5 & 61,550 \\
\hline 1951 & 3386 & $36,336,000$ & 42.6 & 37.4 & 84,300 \\
\hline 1952 & 3350 & $36,081,000$ & 38.8 & 29.5 & 79,650 \\
\hline 1953 & 3349 & $36,255,000$ & 32.3 & 24.1 & 72,750 \\
\hline 1954 & 3333 & $35,860,000$ & 30.1 & 23.5 & 63,850 \\
\hline 1955 & 3235 & $35,017,000$ & 26.5 & 19.6 & 57,507 \\
\hline 1960 & 2934 & $32,601,000$ & 9.9 & 16.3 & 49,153 \\
\hline 1965 & 2425 & $28,755,000$ & 6.1 & 11.1 & $39,100 *$ \\
\hline 1966 & 2275 & $27,182,000$ & N/A & N/A & 51,900 \\
\hline 1967 & 2154 & $25,977,000$ & N/A & N/A & 54,600 \\
\hline 1968 & 2094 & $25,612,000$ & 5.8 & 8.0 & 54,200 \\
\hline 1969 & 1981 & $24,827,000$ & 3.8 & 6.8 & 47,500 \\
\hline 1970 & 1780 & $23,280,000$ & 5.1 & 6.3 & 37,600 \\
\hline 1971 & 1372 & $19,635,000$ & 5.2 & 6.3 & 30,400 \\
\hline 1972 & 1233 & $18,412,000$ & 4.5 & 5.8 & 27,700 \\
\hline 1973 & 1051 & $17,297,000$ & 6.9 & 6.0 & 25,200 \\
\hline 1974 & 965 & $17,334,000$ & 7.6 & 5.8 & 24,800 \\
\hline 1975 & 891 & $17,608,000$ & 5.4 & 5.4 & 20,500 \\
\hline
\end{tabular}

* Strike led to decreased number of workers

\begin{tabular}{|c|c|c|c|c|c|}
\hline No. of Ships & $\begin{array}{c}\text { Deadweight } \\
\text { Tons }\end{array}$ & $\begin{array}{c}\text { \% of Total } \\
\text { Dry Cargo } \\
\text { Trade Carried } \\
\text { by American- } \\
\text { Flag Ships }\end{array}$ & $\begin{array}{c}\text { \% of Total } \\
\text { Tanker Trade } \\
\text { Carried by } \\
\text { American- } \\
\text { Flag Ships }\end{array}$ & $\begin{array}{c}\text { Average } \\
\text { Monthly } \\
\text { Employment } \\
\text { of Seafarers }\end{array}$ \\
\hline 1980 & 863 & $23,679,000$ & 4.8 & 2.6 & 19,600 \\
\hline 1985 & 748 & $24,439,000$ & 5.4 & 3.8 & 13,100 \\
\hline
\end{tabular}




\begin{tabular}{|c|c|c|c|}
\hline & No. of Ships & $\begin{array}{c}\text { Deadweight } \\
\text { Tons }\end{array}$ & $\begin{array}{c}\text { Average } \\
\text { Monthly } \\
\text { Employment } \\
\text { of Seafarers }\end{array}$ \\
\hline 1989 & 661 & $24,457,000$ & 9,900 \\
\hline 1990 & 635 & $24,262,000$ & 11,100 \\
\hline 1991 & 621 & $23,286,000$ & 11,700 \\
\hline 1995 & 564 & $21,126,000$ & 7,900 \\
\hline 2000 & 461 & $16,137,000$ & 6,600 \\
\hline 2003 & 416 & $13,294,000$ & N/A \\
\hline
\end{tabular}

N/A = Not Available

Sources: U.S. Department of Commerce, Bureau of the Census, Statistical Abstracts of the United States, for years 1939-2005; and

http://www.marad.dot.gov/MARAD_statistics/US-FLAG-HISTORY.pdf; Internet:

accessed on 20 June 2006 when information was not available from Statistical Abstracts.

Note on sources: Change in statistical reporting over the years is why import/export topics represented in the table vary. 


\section{Chapter 2: Negotiating Cooperation and Competition: Britain, the U.S., and Merchant Shipping, 1940-1948}

During World War II, the United States and Great Britain engaged in what scholars refer to as the "Special Relationship."18 Even though the United States was technically neutral at the start of the war in Europe, the U.S. gave invaluable assistance to the British war effort. Britain realized early in the war that it needed American assistance to win. Yet, the U.S. and Britain, as they joined together in war, also continued to compete economically. The exigencies of war forced Britain to agree with American policies that conflicted with British strategy, but even as the bombs were exploding during the Battle of Britain, the British continued negotiations for wartime goods with their economic future clearly in mind. However, the pressures of war forced Britain to compromise with U.S. policies to receive the necessary support to survive. The Americans were gaining a superior bargaining position, but Britain achieved muchneeded help from their "neutral” friend.

Britain faced a logistical problem in the early stages of World War II that it did not anticipate: Britain did not possess sufficient merchant shipping tonnage to fulfill its wartime needs. The importance of shipping tonnage became readily apparent once Britain experienced the debilitating effects of not having enough ships. The British turned to the Americans for help. With the advent of the Lend-Lease agreements and the entry of the United States into the hostilities after Pearl Harbor, the U.S. began the largest

18 David Reynolds, The Creation of the Anglo-American Alliance 1937-1841: A Study in Competitive Co-operation (Chapel Hill: University of North Carolina Press, 1982); and Alan P. Dobson, The Politics of the Anglo-American Economic Special Relationship 1940-1987 (New York: St, Martin’s Press, Inc., 1988). 
shipbuilding effort the nation ever saw. The mass production of Liberty ships and T-2 tankers returned the necessary shipping strength to the Allies.

As the Allies neared victory, economic concerns began to dominate AngloAmerican negotiations. The British expected American assistance to stabilize the European economy. The United States likewise recognized that the only way to maintain a strong Western Europe was for the region to have a strong economy. Since the Soviet Union also emerged from World War II as a superpower, the United States and Britain faced a new threat to national security - the spread of Communism. The world was anxious about Soviet intentions, and the ensuing Cold War led to new economic and national security trepidation. The Marshall Plan attempted to address these concerns.

The United States realized that leaving Europe to rebuild itself without American aid, could once again lead to conflict. With the Soviet Union seeking to gain strength by expanding Communism, the United States offered Western Europe monetary assistance to rebuild. Through the Marshall Plan, America reached out to Western Europe in an effort to keep an open market for free trade. ${ }^{19}$

The U.S. built thousands of ships during World War II, and when the war ended, it possessed the majority of the world's shipping tonnage. In order to assist the other Allies in rebuilding their merchant fleets, the U.S. sold many of its wartime ships at discount prices to the traditional maritime nations of Western Europe. ${ }^{20}$ Although the merchant marine proved critical to Allied victory, the importance of maintaining a national fleet of merchant ships would soon be overshadowed by economic and trade considerations.

\footnotetext{
19 Allen W. Dulles, The Marshall Plan, ed. Michael Wala (Providence: Berg Publishers), 1-4.

20 Bauer, A Maritime History of the United States, 311.
} 
In the post-war world, the U.S. and Britain continued to compete economically. If market gain coincided with a lapse of some of the more remote security concerns, the United States was willing to let that happen. The merchant marine was one of these concerns. In pursuit of safe and livable ships, the U.S. developed a system of regulation and seamen's rights that caused American-flag ships to be more expensive to operate than any in the world. In order to reduce shipping costs and thus reduce the overall cost of trade, United States shipowners began to seek less expensive ways to compete in world trade. Instead of attempting to match European prices and operate on an equal trade footing, American interests sought ways to undercut the British and other shippers by turning to flags of convenience. ${ }^{21}$

Panamanian ship registry afforded fewer regulations and lower taxes along with the choice of people of any nationality to man the ships. With many nations being freed from imperial rule, several poor countries offered workers who did not have the luxury of a bargaining position. They were people seeking to survive and were willing to accept low pay and poor conditions afforded on board the Panamanian ships. In 1948, U.S. business interests formed the Liberian ship registry to offer yet another way to circumvent the higher costs of American ships. The Liberian registry was in effect formed by oil companies and subsequently patronized by many American oil interests. ${ }^{22}$

Several businessmen who held influential U.S. government positions were instrumental in the growth of the Panamanian and Liberian ship registries. W. Averell Harriman and Edward R. Stettinius both actively supported the use of these open

${ }^{21}$ Boleslaw Adam Boczek, Flags of Convenience: An International Legal Study (Cambridge: Harvard University Press, 1962), 26-64, 81-90.

${ }^{22}$ See Carlisle, Sovereignty for Sale, for a comprehensive study of the development of the Panamanian and Liberian ship registries. 
registries. Even though the American-flag merchant marine proved to be indispensable during World War II, the close tie between the U.S. government and American business in the drive toward economic hegemony allowed flags of convenience to prosper.

\section{Cautious Partners: Britain and America during the War}

Throughout the war, the United States and Great Britain remained economic competitors. As America assisted the British war effort before Pearl Harbor, the economic power struggle continued. The Destroyers for Bases deal allowed the U.S. to gain strength in its relationship with Britain. While this would benefit the U.S. in future economic trade, the Roosevelt administration knew that it was not in the best interest of its own economy to bankrupt Britain. Since American isolationist factions were powerful at the start of the war, the Lend-Lease program was devised to give the needed assistance without declaring war. Among Britain’s weaknesses was its lack of sufficient merchant shipping capacity to supply its troops and citizens at home and throughout the British Empire. The United States then began the most extensive shipbuilding program in its history, and through Lend-Lease and the use of American-flag ships, solved Britain’s supply problems. However, while grateful that they were receiving needed resources, the British were concerned about the effect that an abundance of shipping tonnage flying the American-flag would have on future trade.

The extensive personal correspondence of Winston Churchill and Franklin D. Roosevelt throughout the war effort best illustrates the emerging relationship between the United States and Great Britain. This correspondence began while Churchill was First Lord of the Admiralty and ended with Roosevelt's death almost six years later. Once Churchill became Prime Minister, British pleas to Roosevelt for American assistance 
began. Churchill wrote to Roosevelt several times to stress the urgency of Britain’s needs. With France on the brink of collapse, Britain would be unable to fight the Nazis without help from the United States. ${ }^{23}$

Because Britain lacked destroyers to protect its coasts and shipping convoys, the British begged the United States for some of its old destroyers. On May 15, 1940, Churchill wrote to Roosevelt asking the United States for, among other things, the loan of "forty or fifty of your older destroyers." ${ }^{24}$ The United States offered to trade destroyers for strategic military bases on British possessions in the Caribbean and Canada. Possession of these bases would give the United States a foothold in an area previously denied it by Britain. ${ }^{25}$

The Destroyers for Bases deal resulted only after a lengthy negotiation between the United States and Great Britain. Britain did not wish to link a trade of navy destroyers to United States use of British colonial lands in the Western Hemisphere. The British desired an exchange of gifts, not a contractual quid pro quo. The United States did not view the deal as such and wanted definite terms laid out for giving the destroyers to Britain. As Britain's position in the war became more untenable, Roosevelt wanted assurances that if he gave them the destroyers, in the event that the British could not hold out, the British navy would not be surrendered. Roosevelt offered that the fleet be taken

${ }^{23}$ Warren F. Kimball, ed., Churchill \& Roosevelt: The Complete Correspondence, I. Alliance Emerging, October 1933 - November 1942 (Princeton: Princeton University Press, 1984), 44-52, (Churchill to Roosevelt, June 12, 1940; Churchill to Roosevelt, June 13, 1940; Roosevelt to Churchill, June 13, 1940; Churchill to Roosevelt, June 14, 1940; Roosevelt to Churchill, June 14, 1940; Churchill to Roosevelt, June 15, 1940).

${ }^{24}$ Kimball, Churchill \& Roosevelt, 37-38, (Churchill to Roosevelt, May 15, 1940).

${ }^{25}$ Charlie Whitham, Bitter Rehearsal: British and American Planning for a Post-War West Indies (Westport:Praeger, 2002), 20. 
to the U.S. in this event so that it would be protected from German capture. The British became suspicious and viewed this proposition as the United States not wanting to give the help needed to save Britain, but that “America was waiting on the sidelines to pick up the pieces.”26 Britain’s responses to Roosevelt’s concerns over the British fleet falling into the hands of Germany impressed upon the United States that it must provide the necessary assistance to Britain before such an event happened or the security of the Western Hemisphere would be threatened whether or not the British fleet was lost. ${ }^{27}$

Since an economic agenda seemed to exist in all Anglo-American dealings, it follows that there would also be economic considerations embedded in what became known as the Destroyers for Bases deal. In correspondence between the United States and Britain, the U.S. muted its economic aims. ${ }^{28}$ But even without declaring an explicit economic agenda, the United States made clear who controlled the new Anglo-American alliance. This would become evident in subsequent economic dealings between the two nations.

The deal was finalized in March 1941. ${ }^{29}$ Britain did not achieve American entrance into the war, but giving a belligerent nation navy war ships could hardly be considered a neutral act. Britain may have lost some of its bargaining power to the Americans, but it achieved a major step toward gaining American help for the Allies.

${ }^{26}$ Reynolds, Creation of the Anglo-American Alliance, 117.

${ }^{27}$ Reynolds, Creation of the Anglo-American Alliance, 116.

${ }^{28}$ U. S. Department of State, Foreign Relations of the United States, 1940, Volume III (Washington, D. C.: U. S. Government Printing Office, 1958), 49-77, (Correspondence between Ambassadors, Secretary of State, Churchill, and Roosevelt, May 16, 1040 - December 30, 1940).

${ }^{29}$ U. S. Department of State, Foreign Relations of the United States, 1941, Volume III (Washington, D. C.: U. S. Government Printing Office, 1959), 84, (Ambassador in the United Kingdom to the Secretary of State, March 27, 1941). 
Now that United States aid was forthcoming, Churchill kept Roosevelt abreast of British war needs. In a letter to Roosevelt on November 12, 1940, Churchill explained what Britain would need in 1941. Among his requests, Churchill asked Roosevelt for surplus merchant tonnage for Britain to purchase. ${ }^{30}$ Submarine warfare and the Battle of Britain created a vacuum in available shipping tonnage for which the British shipbuilding industry was unprepared.

Prior to the beginning of hostilities in Europe on September 1, 1939, the British analyzed the amount of merchant shipping tonnage they would require in order to fight a war with Germany. ${ }^{31}$ They did not estimate all of the factors that could affect their shipping capabilities during the course of the conflict. In addition to actual shipping tonnage, port availability and voyage route availability were crucial to determine what would be required to supply Britain and the Empire. Once the Axis effectively shut down through traffic in the Mediterranean, the voyage from Britain to its South Asian and African colonies was considerably lengthened. Also, given the German U-boat threat in the English Channel and its ability to bomb Britain’s Southern and Eastern ports, British port availability was diminished. ${ }^{32}$ As shipping losses to German submarines in the Battle of the Atlantic mounted, Britain was forced to compensate for its inadequate prewar plans.

The British shipbuilding industry was unprepared to produce the amount of tonnage necessary to keep up with the needs of longer voyages and shipping losses.

30 Kimball, Churchill \& Roosevelt, 102-109, (Churchill to Roosevelt, December 7, 1940).

31 W.K. Hancock and M.M. Gowing, British War Economy, $2^{\text {nd }}$ ed. (London: Her Majesty's Stationary Office, 1951), 120-123.

32 Hancock, British War Economy, 124-126. 
British labor and facilities hindered its progress. Workers who lost jobs when war production ended after World War I were reluctant to let that happen again. Thus there were not as many shipyard workers hired as needed in labor's attempt to prevent large layoffs after the war. British shipyards were also not up to modern standards and shipbuilding executives did not want to change their ways. ${ }^{33}$

The lack of ships put a tremendous strain on British resources. They could not maintain an adequate supply of food and consumer goods in addition to supplying their troops with war materials. Britain turned to U.S. merchant ships. With Britain running out of hard currency, the U.S. established the Lend-Lease program, which sparked the greatest shipbuilding effort in American history. ${ }^{34}$

In December 1940, Churchill again expressed his desire for more shipping tonnage. ${ }^{35}$ Roosevelt responded in a fireside chat to the American people on December 29, 1940 when he argued that the United States must give all aid possible to Britain to contain the Nazis in Europe: "We must be the great arsenal of democracy. For us this is an emergency as serious as war itself.”36 Roosevelt realized that in order to stand against the Germans, Britain needed the assistance of the United States on terms other than cash

33 For a comprehensive discussion of British labor and shipbuilding see Kevin Smith, Conflict over Convoys: Anglo-American Logistics Diplomacy in the Second World War. (Cambridge: Cambridge University Press, 1996), 13-27.

34 At least one British official suggested that Britain should not have worried about its dollar reserves running out because he did not think that the supplies would have stopped even if they had. This thought in the British ministry further strengthens the idea of the special relationship between the U.S. and Britain. Sir Arthur Salter, Memoirs of a Public Servant (London: Faber and Faber, 1961), 266; For a comprehensive and detailed account of the shipbuilding effort during World War II see Frederic C. Lane, Ships for Victory: A History of Shipbuilding under the U.S. Maritime Commission in World War II (Baltimore: Johns Hopkins University Press, 1951; Johns Hopkins Paperbacks edition, 2001).

${ }^{35}$ Kimball, Churchill \& Roosevelt, 112-113, (Churchill to Roosevelt, December 13, 1940).

36 “Radio Address of the President, Delivered from the White House,” (December 29, 1940); available from http://www.fdrlibrary.marist.edu/122940.html; Internet: accessed on 10 November 2005. 
payment. ${ }^{37}$ This preceded passage of the Lend-Lease Act, which provided a means for the United States to become the "arsenal of democracy” without bankrupting Britain.

The Lend-Lease program demonstrated that even during a time of close friendship, the United States and Britain remained economic competitors. Roosevelt's fireside chat of December 29 committed the United States to increase production to aid the British. While Churchill was initially grateful and relieved that the United States passed the Lend-Lease Act, he remained wary of the economic consequences of receiving goods on American terms. ${ }^{38}$ The negotiations between the United States and Britain over the Lend-Lease Agreement were prolonged because Article VII granted freer trade than the British were willing to concede. ${ }^{39}$ Britain viewed Article VII as demanding that Britain give up its policy of imperial preference in exchange for Lend-Lease goods. After assurances from Roosevelt to Churchill that this was not the case, even though Roosevelt expected economic talks to continue, the preliminary Lend-Lease agreement was signed on February 23, 1942. ${ }^{40}$

The British sent Sir Arthur Salter, Parliamentary Under-Secretary in the Ministry of Shipping, to Washington to oversee American aid to the British Merchant Shipping Mission. ${ }^{41}$ With more goods available for British use, a way to transport these goods to

37 Foreign Relations of the United States, 1941, 38, (Memorandum of Conversation, by the Assistant Secretary of State, October 3, 1941).

38 Kimball, Churchill \& Roosevelt, 143, (Churchill to Roosevelt, March 9, 1941).

39 Foreign Relations of the United States, 1941, 38-53, (Correspondence between U.S. State Department and British Ambassador and officials, October 3, 1941 - December 29, 1941).

40 U. S. Department of State, Foreign Relations of the United States, 1942, Volume I (Washington, D. C.: U. S. Government Printing Office, 1960), 535-537, (Roosevelt to Churchill, February 11, 1942).

41 Smith, Conflict over Convoys, 66. 
Britain and its troops was needed. The Liberty ship program applied mass production techniques to the shipyards of the United States. These ships were built quickly to meet the wartime demand and to overpower the Axis with sheer numbers. The Liberty ship program combined with advances made in submarine detection and code-breaking and led to Allied victory in the Battle of the Atlantic.

Toward the end of the war, however, this excess of shipping in American hands worried the British, and thoughts of post-war trade competition began to resurface. The Allied nations who led the world in shipping before the war looked to the United States to return them to their pre-war numbers. In 1943, after the Allies won the Battle of the Atlantic, shipping tonnage was abundant. Now that sufficient tonnage was readily available for all of the Allied needs, Lord Salter remarked that " [t]he whole situation had been so transformed that I found the Commons apparently more concerned with future competition with America than with shipping difficulties in the war (which was after all to last two years more.)"42

Thus, when the Americans showed a desire to build merchant ships that would be more useful commercially than the Liberties, the British kept a close eye on American shipbuilding practices. The Liberty

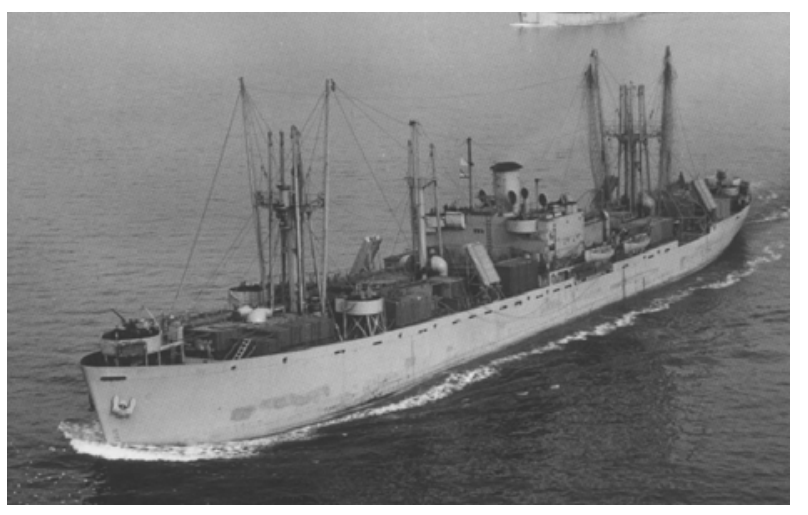

Figure 1 ship (See Figure 1) was easily adapted to the principles of mass production, but was a relatively slow ship at 11 knots. As the program progressed, the Maritime Commission

${ }^{42}$ Salter, Memoirs of a Public Servant, 272. 
developed plans for the similar, but faster Victory ship with a speed of 16.5 knots. ${ }^{43}$ The Liberty ship could be built in greater volumes for wartime needs, but the Victory ship (See Figure 2) would be more useful in a commercial setting after the war.

Consequently, when the U.S. began leaning toward Victory ship construction, the British pushed for more Liberty ships to be built. ${ }^{44}$

\section{Planning for the Post-War World}

Once Allied victory was imminent, the U.S. and Britain looked closer at the structure of the new world economic order. At Bretton Woods and Quebec in 1944, Roosevelt and

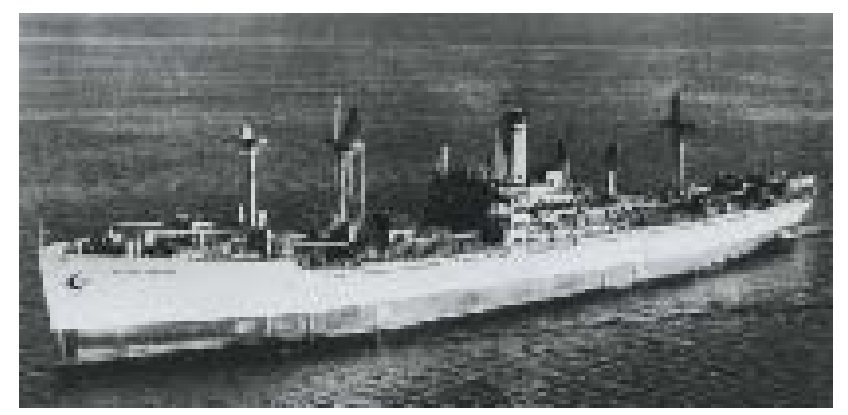

Figure 2 Churchill discussed the rebuilding of Western Europe and the world economy. The Soviets set out on a path of their own after the war, and the threat of Soviet expansion revealed the need for a strong Western European economy. Since American money was needed for this endeavor, the U.S. offered the Marshall Plan to help European nations that rejected Soviet communism rebuild. In addition, an international forum met in the U.S. to organize a world body to prevent another world war from destroying these hardwon arrangements. The massive amount of shipping tonnage now in American hands provided an essential element to rebuild Europe and stabilize world trade. The merchant fleets of the European maritime countries had been devastated by the war, and America was left with the largest merchant fleet in the world. Many of these countries expected the United States to hand out their surplus ship tonnage to return the ratios closer to those

\footnotetext{
43 Lane, Ships for Victory, 28, 574-577.

44 Smith, Conflict over Convoys, 180.
} 
of pre-war times.

The United States and Britain, at conferences at Bretton Woods and Quebec in 1944, took major steps in determining the structure of post-war economic trade. The Bretton Woods conference established monetary exchange stability among western nations. An International Monetary Fund and an International Bank for Reconstruction and Development were set up to promote a strong global economy and provide for the reconstruction of Western Europe. American isolationism and British imperial hegemony were left behind as the dollar became the world's leading currency, surpassing the British sterling. ${ }^{45}$

After Bretton Woods, Roosevelt and Churchill met again at Quebec to decide on a number of remaining issues. They agreed that mutual Lend-Lease assistance would continue after the defeat of Germany during the war against Japan. ${ }^{46}$ Britain also received a favorable position in the division of Germany and was given the industrialized section of Germany to administer after the war. It further received trade routes once dominated by Germany. Secretary of the Treasury Henry Morgenthau felt that this would aid British financial recovery. ${ }^{47}$ This was one of the first steps in moving toward a stable Britain for the post-war period.

45 For a discussion of the issues and compromises of the Bretton Woods Conference see Randall Bennett Woods, A Changing of the Guard: Anglo-American Relations, 1941-1946 (Chapel Hill and London: The University of North Carolina Press, 1990), 115-148; and for a discussion of the preconference plans written by John Maynard Keynes for Britain and by Harry White for the United States and the ensuing compromises see Dobson, Politics of the Anglo-American Economic Special Relationship, 4859.

46 U. S. Department of State, Foreign Relations of the United States, 1944, The Conference at Quebec (Washington, D. C.: U. S. Government Printing Office, 1972), 468, (Memorandum Initialed by President Roosevelt and Prime Minister Churchill, September 15, 1944).

47 Dobson, Politics of the Anglo-American Economic Special Relationship, 70. 
As Western European nations embarked on their post-war recovery plans, the emerging Cold War with the Soviet Union was changing the concepts of traditional national security. The objective of the Marshall Plan was to unite the nations of Europe in a free trade environment thus providing a united and stable economy. The United States decided to provide aid to Europe to prevent economic insecurity from producing a domino effect that would destroy free trade. Since the European economy was linked to trade in many parts of the world where the United States also traded, the end of free trade in Europe would mean an end to free trade throughout the world. ${ }^{48}$ The United Nations and the Marshall Plan were both efforts to provide for economic and national security in Western Europe and the world.

To further both the economic objectives and to provide an international forum for the peaceful resolution of disputes between nations, the United Nations was formed. A conference was convened in San Francisco near the end of the war in April 1945 to organize nations to prevent yet another world war. The economic aspects of world peace were reflected in Chapters 9 and 10 in the Charter of the United Nations. In his report to President Harry Truman on the conference, Edward Stettinius, Secretary of State, emphasized that, in order to maintain a strong American economy, the markets of the world must be healthy. ${ }^{49}$

Ideas expressed at Bretton Woods, Quebec, and in the United Nations were simply words without American shipping tonnage. Europe needed time to recover from

48 "European Recovery and American Aid: A Report by the President's Committee on Foreign Aid (Parts One and Two),” (Washington, D.C., November 1947), B1-B3; available from http://www.trumanlibrary.org; Internet; accessed 16 November 2005.

${ }^{49}$ U. S. Department of State, Charter of the United Nations: Report to the President on the Results of the San Francisco Conference by the Chairman of the United States Delegation, the Secretary of State (June 26, 1945), 109. 
the war, and with the Marshall Plan in place, shipping would provide the means to build a stable world economy.

It would take time for the shipbuilding industry throughout Europe to replenish the European merchant fleets. Western Europe looked to the large American fleet as an interim solution for its shipping needs. One steamship company chairman in Britain suggested that the recovery of the British merchant marine should be accomplished by war reparations and for "[t]he American government to hand over such vessels built, under construction or arranged for, under their flag, to their Allies as necessary to bring up the proportion of shipping owned by them at the outbreak of hostilities." ${ }^{50}$

This assertion may have been the result of wartime agreements between the United States and Great Britain concerning the best way to meet wartime needs. Since American troops and war materials were moving from the U.S. to Britain, Roosevelt and Churchill agreed that merchant ships would be built principally in America. A portion of the completed ships would then be transferred to the British flag for temporary wartime duty so that the pool of experienced British seamen would not go to waste. ${ }^{51}$ The United States answered the post-war European call for ships by offering surplus wartime tonnage for sale under the Merchant Ships Sales Act of 1946. A merchant fleet, thus, for both the U.S. and Europe, was essential to the new world order.

50 J. Hans Adler, "British and American Shipping Policies: A Problem and a Proposal," Political Science Quarterly 59, no. 2 (June 1944): 202.

${ }^{51}$ Warren F. Kimball, ed., Churchill \& Roosevelt: The Complete Correspondence, II. Alliance Forged, November 1942 - February 1944 (Princeton: Princeton University Press, 1984), 219-221, (Roosevelt to Churchill, May 28, 1943); U. S. Department of State, Foreign Relations of the United States, 1943, The Conferences at Washington and Quebec (Washington, D. C.: U. S. Government Printing Office, 1970), 318, n1, (Roosevelt/Churchill exchange on the topic, June 6-7, 1943). 


\section{Flags of Convenience: Competition on the Sea under the New World Order}

While helping the countries of Western Europe along the path of economic recovery, the United States was taking the lead in world economic affairs. At Bretton Woods, the United States introduced the world to an economic system that would be dependent on the dollar. The Marshall Plan also put the U.S. in the forefront of Western European economic recovery. World War II had enabled the U.S. to assume the role of unquestioned leader in world affairs. After World War II, the United States led the world in shipping tonnage, followed by Great Britain. Thus, Anglo-American competition continued into the post-war period. To maintain United States supremacy, American shipowners saw the need to cut their costs to make American trade more competitive in an international setting.

During the war, American merchant seamen who manned U.S.-flag ships in the Battle of the Atlantic and elsewhere, agreed to a no-strike policy and accepted the War Labor Board's regulations setting wages. After the war, seamen returned to collective bargaining under their union agreements. ${ }^{52}$

Shipowners turned then to a new way of controlling wages, that of flags of convenience. ${ }^{53}$ Also referred to as open registries, flags of convenience included ships that, for the most part, had no connection with the flag state other than possibly a dummy corporation formed solely for the purpose of registering a ship. There were generally no

52 Labor-Management Problems, 444.

53 Black's Law Dictionary defines "flag of convenience" as the "Practice of registering a merchant vessel with a country that has favorable (i.e. less restrictive) safety requirements, registrations fees, etc." This is the basic sense in which the phrase is used here. Henry Campbell Black, Black's Law Dictionary: Definitions of the Terms and Phrases of American and English Jurisprudence, American and English Jurisprudence, Ancient and Modern (St. Paul: West Publishing Co., 1979), 574. 
citizenship requirements for an owner to register a ship under that flag. Flag of convenience ships were typically manned by seamen from poor countries who had little or no bargaining power and therefore at times were not provided with sanitary living conditions and were paid at the whim of the owners. Flag of convenience ships allowed non-union labor, tax incentives, and relaxed safety regulations, all to lower operating costs for shipowners.

Flags of convenience provided a way to reduce American shipping costs to a level below what the Western European nations could offer on board their ships. The United States began its flag of convenience practices through the use of the Panamanian flag, and later created a flag of convenience registry in Liberia which offered less hassle than the Panamanian registry.

Flags of convenience had been used throughout the twentieth century for various reasons. The most popular rationalization in the early years of the century was to avoid the negative effects of neutrality laws during wartime. Many shipowners used the flags of other countries to avoid their own countries' neutrality laws so they would not lose money by being denied access to certain trade routes. Yet in the end, the core purpose of the flag of convenience registries was to circumvent the laws of the owner's home nation to achieve higher profits. ${ }^{54}$

The Panamanian flag of convenience had a long history of being used for a number of purposes. After the Volstead Act went into effect in 1920, alcoholic drinks could no longer be served on board American-flag ships. This was particularly devastating to the cruise ship industry. One American shipowner, W. Averell Harriman,

${ }^{54}$ Carlisle, Sovereignty for Sale, 71-97. 
who later entered politics, owned several American-flag ships, including two passenger liners, the Reliance and the Resolute. In 1922, he transferred the ships to the Panamanian flag in order to avoid the restrictions of Prohibition that the Attorney General extended to American-flag ships. Harriman preferred the Panamanian registry because of the close relationship between the United States and Panama after the opening of the Panama Canal in 1914. This not only allowed the American-owned cruise ships to better compete with foreign ships in offering similar amenities to passengers, but it also revealed to American businessmen other advantages. Customs duties and higher crew costs could be avoided by patronizing the Panamanian flag. ${ }^{55}$

Panamanian registry was again used by U.S. shipowners on the eve of World War II to bypass the Neutrality Acts of the 1930s that forbade U.S.-flag ships from entering war zones. As World War II ended, the Panamanian registry became more complicated and thus less convenient. Some American oil corporation interests through the late 1940s were flagging their ships in Panama, but the situation in Panama turned bad in 1947 when a wave of anti-American feelings culminated in a week of rioting in Panama City. This, in addition to contemporary political changes in Panama, upset the purpose for which owners flocked to a flag of convenience. ${ }^{56}$

Edward Stettinius, who served as Secretary of State under Roosevelt and Truman, and several of his oil industry associates, created an opportunity in Liberia that several oil tanker owners embraced. While Secretary of State in 1945, Stettinius traveled to Liberia after the conference at Yalta to celebrate the opening of the Port of Monrovia. As a

\footnotetext{
55 Carlisle, Sovereignty for Sale, 14-18.

${ }^{56}$ Carlisle, Sovereignty for Sale, 113-114.
} 
former chairman of the board at U.S. Steel, however, he noted that the country was rich with natural resources. The Liberian ship registry grew out of the efforts of Stettinius Associates, a corporation formed by Stettinius in 1947 to create "a system of privately directed economic aid to Liberia." ${ }^{57}$ With the encouragement of American oil interests, the Liberian ship registry resulted from collaboration between Stettinius Associates and the Liberian government. Also, the United States government actively supported the formation of the Liberian ship registry. The State Department conducted a review of its provisions before it was adopted and suggested several changes to the code. The Liberian ship registry was basically operated out of the United States with a percentage of the fees collected going to the Liberian government. ${ }^{58}$

American oil interests also helped form the rules of the new Liberian registry. Standard Oil Company executives, for example, reviewed the registry law prior to its adoption. ${ }^{59}$ Liberia now offered a haven for shipowners, approved by the American government and operated almost exclusively by Americans, to reduce their operating costs, and ultimately to offer better trade incentives than the Europeans.

To address national security concerns amid growing Cold War tensions related to the decrease the Liberian registry would cause in U.S. registry, the American government adopted the doctrine of "effective control of shipping." This principle provided that in time of war, flag of convenience ships that were owned by American interests would be

\footnotetext{
${ }^{57}$ Carlisle, Sovereignty for Sale, 115.

${ }^{58}$ Carlisle, Sovereignty for Sale, 115-129.

${ }^{59}$ Carlisle, Sovereignty for Sale, 123.
} 
under the effective control of the United States. ${ }^{60}$ This would enable the United States government to requisition these ships in time of need for use in a war effort. The reliability of a program that depended on foreign citizens to support U.S. foreign policy was questioned by some members of Congress. During the Vietnam War several foreign crews refused to take ships carrying American supplies into the war zone. Senator Warren G. Magnuson, chairman of the Senate Committee on Commerce in 1967, testified at a hearing concerning the condition of the American merchant marine that "I do not think you can use the words 'effective control' on a ship built with American money in an English yard flying a Liberian flag chartered by a Greek corporation with Italian officers and an Indian crew in the Straits of Suez... And there are many examples of that." ${ }^{\prime 1}$ He presented a specific instance when a Mexican crew refused to sail a ship with American war supplies because it violated Mexican neutrality laws. When that cargo was transferred to a Greek ship, part of that crew refused to sail because of political reasons. Thus, a cargo bound for American troops in Vietnam was delayed for over two weeks. ${ }^{62}$ Also at that hearing, Alfred Maskin, representing the American Maritime Association, an organization of shipping companies operating unsubsidized Americanflag vessels, summed up the doctrine when he declared, "how much effective control we exercise over a ship depends in a great measure on who mans the ship...."63 Nevertheless, at the time of the formation of the Liberian registry, effective control

\footnotetext{
${ }^{60}$ For a comprehensive discussion of U.S. effective control of shipping see Boczek, Flags of Convenience, 188-208.

${ }^{61}$ U. S. Congress, Senate, Committee on Commerce, Subcommittee on Merchant Marine and Fisheries, U.S. Maritime Policy, 90 ${ }^{\text {th }}$ Cong., ${ }^{\text {st }}$ sess., 13 April 1967, 55.

62 U.S. Maritime Policy, 56.

63 U.S. Maritime Policy, 407.
} 
dictated how national security interests would be met after the Liberian flag of convenience drew ships away from the American-flag fleet. This doctrine is still used today to defend the usefulness of flags of convenience even though there were several instances similar to those in Vietnam that occurred during the Persian Gulf War in the early 1990s. ${ }^{64}$

\section{The Effect of International Competition}

America and Great Britain have been economic competitors since before there was a United States. Even through the turmoil of the Second World War, Britain fought to keep its world economic position as the United States strived for hegemony. Economics and national security ran hand in hand. Even though circumstances at times raised doubts about the very future of Britain, Churchill never allowed the complete sacrifice of British economic policy in order to obtain help in fighting the Germans. Furthermore, when faced with the danger that a loss of Britain would pose to the Western Hemisphere, the United States in effect gave massive amounts of materials to the Allies without monetary compensation.

Although economics is seldom forgotten during times of war, proven national security entities have been allowed to lapse in times of peace. The American-flag merchant marine was instrumental in defeat of the Axis powers, but when the violence of the war ceased, cheaper alternatives to the U.S. merchant fleet were immediately sought. American business interests and U.S. government policy were united in purpose by

\footnotetext{
${ }^{64}$ U. S. Congress, House, Committee on Merchant Marine and Fisheries, Subcommittee on Merchant Marine, Operation Desert Shield/Desert Storm Sealift Performance and Sealift Requirements, $102^{\text {nd }}$ Cong., ${ }^{\text {st }}$ sess., 23 April 1991, 21-23.
} 
individuals like Harriman and Stettinius who played important roles in both government and business.

Since the Liberian and Panamanian ship registries offered American owners a less expensive method of promoting overseas trade, the future of the United States-flag merchant marine did not look bright. The British-flag fleet faced similar challenges. With the American ability to undercut British shipping costs by using less expensive ships, it would be only a matter of time before Britain would also have to turn to flag of convenience shipping in order to compete.

The lessons of World War II were short lived where merchant shipping tonnage was concerned. Even though both the United States and Great Britain had just experienced the importance of merchant shipping to maintain national security, post-war economic concerns took precedence. In the emerging world of economic dominance, the top two nations in world shipping elevated economics above national security. Economic competition began to lead the world firmly on a path that would change the face of merchant shipping.

With the cessation of hostilities and the economic recovery of Western Europe underway, wartime ships entered commercial operations. Technology that was introduced during the war was improved and advanced to create more efficient and better ships. Western European nations and the Soviet Union began building up their national fleets, while the flag of convenience registries continued to grow. The U.S. government focus turned to peacetime economic growth, but rather than pursuing its policy of maintaining a strong merchant marine, it openly supported and allowed shipowners to migrate to flags of convenience. 
As the shipowners, shipyards, shippers, and maritime labor all adjusted to the new world order and the rising American economy, the parties began to pursue their individual interests. When the U.S. government attempted to support each group separately, animosity between the parties grew. As the maritime factions quarreled, progress in the industry stopped. 


\section{Chapter 3: Policy, Labor, and Technology: The Beginning of the Downward Spiral, 1946-1984}

The United States-flag merchant marine faced new challenges after the war. The Liberian ship registry was in full operation and offered economic advantages to shipowners. The American labor force was bargaining for better wages and working conditions, and unions were again becoming a strong factor in the industry. Researchers devised technological innovations that saved money and made work more efficient while lowering the number of general laborers needed in the work force. Finally, the new leader of the free world began a campaign seeking world economic leadership, industrial and trade regulation, and maintenance of security during the emerging Cold War.

Shipowners attempted to bypass the stricter regulations, taxes, and crew requirements of the U.S. flag by registering their ships under flags of convenience to an extent unprecedented to that time. Using the new Liberian ship registry instituted by Stettinius and others after the war, many American shipowners sought to lower their operating costs and increase profits. Some of the ships transferred to flag of convenience registries were from the surplus of Liberty ships and T-2 tankers left over from the World War II shipbuilding bonanza. ${ }^{65}$

Because the United States possessed too much shipping tonnage for American business to absorb, in 1946, Congress passed the Merchant Ship Sales Act to enable the United States government to sell its surplus wartime shipping tonnage. In addition to providing rules for the transfer of war-built ships from government operation to American private corporate control, the Sales Act allowed foreign citizens, particularly

${ }^{65}$ Carlisle, Sovereignty for Sale, 111. 
those of the Allied nations of World War II, to acquire U.S. war-built ships that were in excess of what U.S. businesses could effectively operate. The authority of the government to sell and charter vessels under the Sales Act ended on December 31, 1947. ${ }^{66}$ This date was extended several times in order to distribute the extra ships, and this act has also been amended numerous times over the years.

One section of the Sales Act remains untouched to this day: the "Declaration of Policy." ${ }^{\text {}}$ This policy concentrated on maintaining an American-flag merchant marine for both economic growth and national security interests. Nevertheless, even with the continued emphasis on preserving a viable merchant fleet under the U.S. flag, Congress never restricted American business in its use of open registries. In fact, through its support of the Panamanian and Liberian registries, the American government encouraged their continued use and thus the shrinking of the nation's merchant fleet.

The turn to open registries contributed also to labor unrest during the 1950s and 1960s. Maritime labor leaders saw shipboard jobs passing to the seamen of third world countries who were willing to work under reduced safety and living conditions for much

${ }^{66}$ U.S. Congress, $79^{\text {th }}$ Cong., $2^{\text {nd }}$ sess., Ch. 82, Merchant Ship Sales Act of 1946, Sec. 2, 08 March 1946.

67 Section 2 of the Merchant Ship Sales Act of 1946 states

(a) It is necessary for the national security and development and maintenance of the domestic and import foreign commerce of the United States that the United States have an efficient and adequate American-owned merchant marine (1) sufficient to carry its domestic water-borne commerce and to provide shipping service on all routes essential for maintaining the flow of such domestic and foreign water-borne commerce at all times; (2) capable of serving as a naval and military auxiliary in time of war or national emergency; (3) owned and operated under the United States flag by citizens of the United States; (4) composed of the best-equipped, safest, and most suitable types of vessels, constructed in the United States and manned with a trained and efficient citizen personnel; and (5) supplemented by efficient American-owned facilities for shipbuilding and ship repair, marine insurance, and other auxiliary services.

(b) It is hereby declared to be the policy of this Act to foster the development and encourage the maintenance of such a merchant marine. U. S. Department of Transportation, Maritime Administration. Compilation of Maritime Laws (Washington, D.C.: U.S. Government Printing Office, 2005), 339; 50 U.S.C. App. 1735 (2004). 
less money than an American seaman could survive on living in the United States. ${ }^{68}$ In addition to the competition imposed from foreign seamen, American seamen faced a reduction caused by technological innovation in the maritime industry. Possibilities of new methods of propulsion, automated engine rooms, and more efficient cargo handling and stowage techniques threatened to substantially cut the shipboard labor force. Malcolm McLean's new containers were instrumental in changing cargo handling and ship design.

Congress held many hearings regarding labor-management problems, subsidy control, shipbuilding in American shipyards, and overall more efficient means of competing in the international shipping market. This effort to determine problems and solutions to the ever-dwindling American-flag fleet led to amendments and alteration of existing merchant marine legislation. From the Merchant Marine Act of 1936 through the 1980s, all the discussion about problems in the industry led not to a solution, but only to further discussion. The U.S. government had the ability to oversee all groups in the maritime industry. In its new position as world leader, through foreign policy, industry regulation, and government aid, the national government was the major player in determining whether the U.S. flag would survive in international trade.

Without government guidance and regulation, the diverse parties in the maritime industry were left to fend for themselves. Pleasing various political constituencies has long been a concern of American politicians. The controversy surrounding the perceptions of different interest groups in the need for a viable American-flag merchant fleet and the method in which to attain it resulted in harmful delays in either updating

68 Joseph P. Goldberg, The Maritime Story: A Study in Labor-Management Relations (Cambridge: Harvard University Press, 1958), 229-231. 
standing maritime policy or in developing methods in which to achieve the goals of the current policy. The American-flag merchant marine was inundated with wartime ships built quickly with defective technology and low-quality steel. Labor faced work force reduction from new technologies and from flags of convenience. Shipowners struggled against lower-cost foreign competition. The lack of government guidance and regulation during this turbulent time encouraged internal bickering between the different factions of the maritime industry. The government's failure to support an American merchant fleet and effectively regulate the diverse parties and interests of the maritime industry initiated the decline of the U.S.-flag merchant marine.

\section{Unions, U.S. Policy, and the Post-War World Maritime Order}

The main conflicting interests within the maritime industry pitted shipowners and shippers seeking to reduce costs against labor unions fighting for higher wages and good working conditions. To complicate matters, different interests within each faction did not always pursue the same goals. Shipowners clashed over trade routes; shippers looked for low costs, but also for safe transit of their goods; and labor unions did not always agree on how to best represent their members. When the focus in shipping returned to the commercial market after the war, a prudent congressman could not summarily dismiss any one of these interests without considering how that would affect his chances for future election. Hence, Congress hesitated to take definitive action in the maritime industry. Instead of regulating the actions of these diverse parties in the interest of maintaining a national merchant fleet, Congress concentrated on providing subsidies to satisfy some shipowners and labor while it allowed other shipowners to transfer their ships to flags of convenience. 
Seamen after World War II began once again to engage in collective bargaining with their employers. ${ }^{69}$ Considering the size of the American fleet at this time, with the rebuilding of the European economies and security of the free world in addition to the rising tension in Korea, American merchant seamen were in demand. Yet seamen, who had received bonuses and other extras during the war, suddenly returned to their base wages. The need for seamen gave the unions the power to demand increases in basic wage rates at least to be in line with the rising standard of living in the United States. ${ }^{70}$

During the early post-war years, several seamen’s and officers’ unions represented American labor on board ship. In the atmosphere of the Cold War, the old communist factions within the seamen’s unions were becoming unpopular. Even so, from his leadership position in the International Longshoremen and Warehousemen’s Union (ILWU), Harry Bridges had great influence on maritime labor, especially on the west coast. His agreement with many policies and ideals that were labeled "communist" caused friction with other labor leaders in the industry, notably Harry Lundeberg of the Sailors’ Union of the Pacific (SUP) and the Seafarers’ International Union (SIU). All seamen's unions progressively became more interested in gaining rights for their membership than in embracing political ideology. ${ }^{71}$ This general agreement on not taking specific political stands, however, did not lead the different unions to merge into one at this time. Several concerns of the individual unions still differed and caused

69 Labor-Management Problems, 444.

70 Elmo Paul Hohman, History of American Merchant Seamen (Hamden: Shoe String Press, 1956), 94-95.

71 Hohman, History of American Merchant Seamen, 101-103. 
animosity within the maritime environment. This was compounded on some ships when several unions made up a crew.

The NS Savannah, America’s first nuclear-powered merchant ship, demonstrated the problem of too many unions in one crew. Members from five different maritime unions were employed on board the Savannah during States Marine Lines' operation of the vessel. The four unions that spoke for the ship’s officers were the International Organization of Masters, Mates and Pilots (MMP) representing the licensed deck officers; the Marine Engineers’ Beneficial Association (MEBA) speaking for the licensed engineering officers; the American Radio Association (ARA) acting for the licensed radio officers; and the Staff Officers’ Association (SOA) covering the pursers. The unlicensed members of the crew were supported by the National Maritime Union (NMU). ${ }^{72}$ Animosity arose from the very beginning between the several unions and States Marine Lines, and also between the different unions and their representative members.

The most outspoken union on board the Savannah was the MEBA. MEBA bargained with States Marine Lines mainly through Jesse Calhoon, who was secretarytreasurer at the beginning of the negotiations until he became president of the union in 1963. The engineers were concerned about many items including wages during the training phase of their employment, shipboard accommodations, manning scales, and a number of smaller items they were not happy with. There was no collective bargaining agreement between States Marine Lines when the engineers finally boarded the ship after training, and consequently they refused to sail. MEBA arranged a temporary agreement

\footnotetext{
72 David Kuechle, The Story of the Savannah: An Episode in Maritime Labor-Management Relations (Cambridge: Harvard University Press, 1971), 49.
} 
with the operating company, and the ship conducted sea trials in March and April of 1962. When the Maritime Administration turned the ship over to States Marine Lines on May 1, 1962, the parties had still not settled on a final labor agreement. The engineers again refused to sail the ship. ${ }^{73}$

As negotiations with MEBA progressed, the other unions became suspicious of MEBA's intentions, and they wanted their due compensation too. This disagreement culminated in a complicated arbitration proceeding followed by a challenge of the arbitration award in the New York Supreme Court. The New York courts upheld the arbitration award in early 1963. On February 12, 1963, the Savannah docked in Galveston, Texas, which was to be its home port. ${ }^{74}$

Repairs were planned for the stay in Galveston, and then in May the Savannah was scheduled to make a trip to thirty five countries around the world. As departure time for the world voyage approached, the engineers were still not happy with the arbitration award. When they refused to sail the ship in May, States Marine Lines tried to solve the dispute, but a compromise was not forthcoming between the several unions. The Maritime Administration dismissed States Marine Lines and put the operator contract up for bid. ${ }^{75}$ In July 1963, American Export Isbrandtsen Lines and its contracted unions entered into a “no-strike” agreement with the Maritime Administration. After the new

\footnotetext{
73 Kuechle, Story of the Savannah, 73-89.

74 Kuechle, Story of the Savannah, 104-167.

75 Kuechle, Story of the Savannah, 169-208.
} 
personnel were trained, the Savannah went on its mission without further problem or delay. ${ }^{76}$

Attempts at automation on board conventionally-powered ships also caused labor unrest. ${ }^{77}$ Automated ships meant fewer jobs for shipboard personnel. With the American merchant fleet in decline and the vast number of its ships aging past their useful lives, union leaders would have been remiss in their duties to allow reduced manning scales without a fight. In Congressional hearings held in 1966 by the House Merchant Marine and Fisheries Committee, William B. Rand, president of United States Lines, a U.S.-flag liner shipping company, empathized with labor in its attempt to stop the reduction of manning on automated vessels. He stated that union reluctance to reduced manning resulted from the fact that "[t]he unions see absolutely no future whatsoever and ... if we could have something to shoot at, a goal of an increased American merchant marine, we could obtain all sorts of cooperation from the unions in the reduction of crews." ${ }^{78}$

Despite the many union disagreements, the unions concurred in other areas, particularly concerning the increasing use of flag of convenience shipping. As the Liberian ship registry grew with ships owned by American interests, the seamen's unions not only fought back, but also were joined by the European nations that had strong maritime traditions. American seamen and European governments argued "that flags of

${ }^{76}$ U.S. Congress, Senate, Committee on Commerce, Subcommittee on Merchant Marine and Fisheries, The Nuclear Ship “Savannah.” $90^{\text {th }}$ Congress, $1^{\text {st }}$ sess., June 12, 1967, 3-4.

77 See Kuechle, Story of the Savannah, 281-284.

${ }^{78}$ U. S. Congress, House, Committee on Merchant Marine and Fisheries, Subcommittee on Merchant Marine, Vietnam-Shipping Policy Review, Part 1. 89 $9^{\text {th }}$ Cong., $2^{\text {nd }}$ sess., 08 March 1966, 120. 
convenience were unethical legal fictions designed to escape the safety controls, social legislation, taxation, and maritime policies required by other nations.”,79

Although the American seamen and the Europeans were driving toward the same goal, they approached the matter from different sides. The European argument stemmed from the international competition during the war. U.S. and British competition for economic and trade superiority continued after the war with most of the European maritime nations siding with Britain on matters of ship registry. Europe viewed the use of flags of convenience by American shipowners as a method of unfair competition. The European nations sought a way to force ships to be registered in the country of the owner or in a country customarily associated with maritime activities. ${ }^{80}$

Europeans stressed their opposition to flags of convenience at the United Nations Conference on the Law of the Sea held at Geneva in 1958. Conflict arose over how the nationality of a ship should be determined under international law. The controversial statement was "for purposes of recognition of the national character of the ship by other states, there must exist a genuine link between the state and the ship.”81 The nations involved on both sides knew that the "genuine link" part of this phrase was ambiguous enough that it wouldn't cause a problem to either side. However, the flag of convenience supporters, mainly Liberia, Panama, and the United States, were against including the "recognition of the national character of the ship" part of the statement. ${ }^{82}$ The United States suggested that instead of associating a "genuine link" with the "recognition of the

\footnotetext{
${ }^{79}$ Carlisle, Sovereignty for Sale, 152.

${ }^{80}$ Carlisle, Sovereignty for Sale, 152.

81 Boczek, Flags of Convenience, 247.

82 Boczek, Flags of Convenience, 248.
} 
national character of the ship," it would be better to require the flag state to "exercise control and effective jurisdiction” over vessels under its registry. ${ }^{83}$ Since this phrase in effect turned out to be as vague as the "genuine link" concept, the character of flag of convenience registries was not substantially altered, and the practice of open registry continued. ${ }^{84}$

In their fight against flags of convenience, American seamen turned to the forces of domestic and international labor and to the American courts. Joining with the International Transport Workers Federation (ITF), an international organization that looked after the rights of workers in the transportation industry, the American maritime unions fought to nullify the advantages of the flag of convenience registries by requiring labor on board ships to be organized by unions from the nation of the shipowner, not of the flag state.

Through a system of boycotts and organizing efforts, the unions from 1958 through 1962 disrupted flag of convenience operations. ${ }^{85}$ American seamen's unions brought the National Labor Relations Board (NLRB) into their fight to organize foreign seamen under their unions. The NLRB applied a test where, if the ship and its owners had sufficient contact with the United States, the NLRB would have jurisdiction over labor matters on board those ships instead of the flag state. This would make American labor law apply on board American-owned flag of convenience ships, and the unions would be free to conduct their organizing efforts on board those vessels. This looked like a union victory over open registries, but the United States Supreme Court stepped in and

\footnotetext{
83 Boczek, Flags of Convenience, 259.

${ }^{84}$ Carlisle, Sovereignty for Sale, 155.

${ }^{85}$ Carlisle, Sovereignty for Sale, 158-159.
} 
ruled that this was not so. Even though it was not obligated by the facts of the specific case before it to rule as definitively as it did, the Supreme Court effectively cleared up the entire issue of the applicable labor law on board flag of convenience vessels. The Supreme Court "concluded that the jurisdictional provisions of the [National Labor Relations] Act do not extend to maritime operations of foreign-flag ships employing alien seamen.” ${ }^{86}$ Congress in effect signaled its agreement with this ruling by not legislating otherwise. Therefore, the Supreme Court decision formed the applicable law. ${ }^{87}$

It is not surprising that the U.S. Congress did not act on this issue. There were several conflicting sides in this dilemma that would have trapped many congressmen in politically disadvantageous positions. With the European governments and the seamen's unions fighting to restrict flag of convenience registries and the shipowners claiming that they could not survive economically under the American flag, the United States government agreed with business that transfer of ships to these open registries should not be burdened with limitations. After all, it was W. Averell Harriman, who served as a government official under several U.S. presidents, including Secretary of Commerce under President Harry Truman, who re-flagged his ships in Panama in the 1920s to avoid the Prohibition laws. And it was Edward R. Stettinius, Secretary of State under Presidents Roosevelt and Truman, who developed the Liberian ship registry. ${ }^{88}$

\footnotetext{
${ }^{86}$ Carlisle, Sovereignty for Sale, 169.

${ }^{87}$ Carlisle, Sovereignty for Sale, 158-170.

${ }^{88}$ Carlisle, Sovereignty for Sale, 15-18, 115-133, 154-155.
} 


\section{The U.S.-Flag Merchant Marine and Changing Technology}

As the battle over flag of convenience registries was raging, the maritime industry adjusted to changing technology. Companies were developing new methods of cargo handling and ship propulsion for more economical, less labor-intensive operations. New technologies in containerization and engine propulsion changed the way ships operated in international commerce. Nations around the world modernized their ports for the intermodal system of transportation introduced by the container revolution. Yet throughout the innovation of the maritime industry, there remained an abundance of warbuilt ships that operated in commercial trade.

In the mid-1950s, in fact, the American-flag merchant marine was mainly composed of World War II-era ships. These ships were built for quantity, not quality, and the quality of steel being used combined with the new method of all-welded construction was causing cracks in the ships’ plating. This problem was so prevalent that it resulted in ships breaking in half not only under the stress of sea conditions, but also while moored at the dock. Because these ships were used so widely in the commercial trades, many more casualties occurred in the 1950s and 1960s due to cracks in the steel plate.

The problems with cracks in all-welded construction of ships during World War II was early demonstrated by the new tanker, Schenectady, when it broke in half at the dock on the evening of January 16, 1943 shortly after it completed its sea trials. (See Figure 3.) In the old system of ship

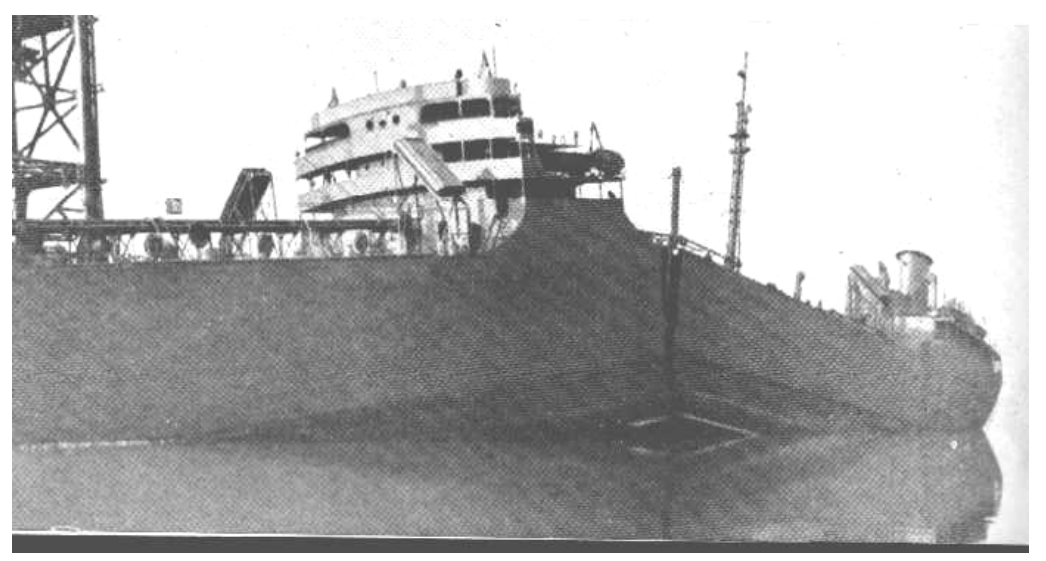


construction, steel plates were riveted together to form the hull. If a crack started in one plate, it would in most cases stop at the riveted seam. However, with all-welded construction, a crack would continue through the welded seam and across the subsequent plates around the entire hull. While there were several contemporary instances of ships breaking due to cracks in the steel, the Schenectady incident was fully reported in the public news since it happened at the shipyard, where others were kept secret due to security reasons associated with the war. ${ }^{89}$

Shipyards began taking precautions against the complete breaking up of ships by installing reinforcing straps and crack arrestors, but it was imperative to the war effort that the shipbuilding program continue at its current rate of production. Investigation of these incidents left uncertainty over whether the cracks were caused by the stress of allwelded construction, the quality of steel, or a completely different reason. Since the steel plates were being manufactured by several different steel mills, the damages could not at that time be definitely traced to substandard steel plating. The Maritime Commission did not want to reduce steel production by imposing higher standards on the steel mills, and since the cause of the cracks had not been specifically pinned down to faulty steel plating, production continued as before. ${ }^{90}$

Further investigation of this matter after the war showed that it was not only the welded construction alone that was causing the problem, but also, as Dr. Constance Tipper, a British metallurgist and mechanical engineer, showed, when exposed to certain conditions, the poor quality of steel used in the war-time ships would become brittle and

\footnotetext{
89 Lane, Ships for Victory, 544-545.

90 Lane, Ships for Victory, 550-552, 572-573.
} 
crack. ${ }^{91}$ Even though the problems with cracks in the hull were well known, war-built ships were sold to private interests, foreign and domestic, to be used in the deep-sea shipping trade. During the 1950s and 1960s, there were reported instances of Liberty ships and T-2 tankers breaking up at sea.

The Marine Merchant was a Liberty ship built in 1944 in Portland, Maine. In 1947, it was converted to carry bulk cargoes and was still engaged in that trade on April 14, 1961, when it carried a bulk cargo of sulfur on a voyage from Louisiana to Maine. Late on the evening of April 13, the ship ran into heavy weather off the New Hampshire coast. The captain ordered the vessel hove to in order to ride out the storm. Yet, at about 10:30 that evening the vessel's hull cracked with a loud bang. The captain ordered the engine stopped and the crew to ready the lifeboats. The hull fracture was so severe that the radio antenna sagged with the damage to the hull and grounded out on the radar scanner. The radio operator was eventually able to send a distress signal, following emergency repairs to the antenna, which alerted the Coast Guard station in Boston, Massachusetts and all ships in the area to the problem. Since the deck plating was holding the two halves of the ship together, the captain felt that it was safer for the crew to remain on board the ship than to brave the storm in the lifeboats. Early on the morning of April 14, the captain decided weather conditions had improved while the ship’s condition had worsened, so he ordered the crew to abandon ship. Later that morning, the entire crew was picked up by two other ships in the area. Shortly after 9:00, the Marine Merchant disappeared beneath the sea. The Coast Guard attributed this event in part to

91 “Constance Tipper, 101, Is Dead; Found Strategic Flaw in Ships,” New York Times, December 24, 1995, 26; for a comprehensive study of the tests and findings of Dr. Tipper's examination of the quality of steel plate see C. F. Tipper, The Brittle Fracture Story (Cambridge: Cambridge University Press, 1962). 
the "inherent weakness incident to structural notch sensitivity, common to welded vessels of this class." 92

Two T-2 tankers met similar ends on the same fateful day, February 18, 1952, in a severe storm off the coast of Cape Cod. The Pendleton was built in 1944 and the Fort Mercer was built in 1945, both part of the war-time shipbuilding program. The Pendleton, carrying a cargo of kerosene and heating oil, experienced a hull failure with a loud cracking sound at about 5:50am. The bow and stern sections separated, leaving the crew on the bow section with no power. A distress signal was never sent. ${ }^{93}$ Meanwhile, a short distance to the east of the Pendleton, the Fort Mercer was also riding out the same storm. At about 8:10am, the crew heard a loud bang and saw oil coming from below the water in the midship area of the vessel. The captain slowed the ship and called the Coast Guard for assistance. Coast Guard units then set out to help the Fort Mercer. Before they arrived, the crew heard another loud bang from the hull, and then a little over an hour later heard a third bang. The captain kept the Coast Guard and other ships in the area advised of the condition of the Fort Mercer and urgently requested help. A short time after noon, the ship split in two. ${ }^{94}$

The Coast Guard conducted simultaneous rescue operations for the two ships. Nine crewmen from the Pendleton perished while five were lost from the Fort Mercer. ${ }^{95}$

92 U.S. Coast Guard, Marine Board of Investigation; SS MARINE MERCHANT, O/N 245750; structural failure and ultimate sinking, 14 April 1961, Gulf of Maine, 1961, 1-5, 9.

93 U.S. Coast Guard, Marine Board of Investigation; structural failure of tanker PENDLETON off Cape Cod on 18 February 1952, with loss of life, 25 September 1952, 3-5.

94 U.S. Coast Guard, Marine Board of Investigation; structural failure of tanker FORT MERCER off Cape Cod on 18 February 1952, with loss of life, 25 September 1952, 3-4.

95 PENDLETON, 1; FORT MERCER, 1. 
Both of these ships had been fitted with crack arresters and other modifications resulting from the discoveries made during wartime operations. ${ }^{96}$ The Coast Guard determined in both cases that the inherent nature of T-2 type vessels to crack was a factor. ${ }^{97}$ This was the end of service for the Pendleton. ${ }^{98}$ However, the Fort Mercer remained in the cargo trade for another twenty two years. The stern of the Fort Mercer was rebuilt with a new bow section and ran until late 1983 when it was scrapped in Bangladesh. ${ }^{99}$

While these wartime ships were being used for commercial post-war trade in the mid-1950s, leaders in government and transportation sought more efficient methods of powering ships and of moving cargo. In 1953, President Eisenhower in his “Atoms for Peace” initiative introduced the possibility of using nuclear energy for peaceful means. In 1965, the first nuclear-powered merchant ship to venture out on the high seas, the NS Savannah, began cargo-passenger service. Cargo movement, however, by 1956 was on its way to entering a whole new era in the transportation industry, containerization. Malcolm McLean was the premier force in this transition.

McLean entered the trucking business in 1931 when there was no reliable transportation in his home farming community in North Carolina. He expanded his

96 PENDLETON, 2; FORT MERCER, 2.

97 PENDLETON, 10, 13-14; FORT MERCER, 10, 13-14.

98 U.S. Dept. of Transportation, Maritime Administration Vessel Status Card System; available from https://marad.dot.gov/marad_statistics/vsc/search.asp, Pendleton; Internet: accessed on 22 February 2006.

${ }^{99}$ Maritime Administration records show a vessel which meets the characteristics, shipyard, date of construction, operator, and gross tonnage of the Fort Mercer referred to by the Coast Guard. The Coast Guard report lists the vessel's official number as “24884” while the MARAD records list it as “248894.” Since other vessels built during this time period have six-digit official numbers, and due to the close resemblance of the two numbers, it can be assumed that the Coast Guard records are in error and the ship scrapped in 1983 is the same vessel that broke in two off Cape Cod in 1952. U.S. Dept. of Transportation, Maritime Administration Vessel Status Card System; available from https://marad.dot.gov/marad_statistics/vsc/search.asp, Fort Mercer; Internet: accessed on 22 February 2006; FORT MERCER, 2. 
business to several trucks, and began moving products along the east coast. While waiting to unload his truck one day at the port of Hoboken, New Jersey, he noticed that the movement of goods from truck to ship was very inefficient. From this experience, he began a journey that led to the complete innovation of the shipping industry. ${ }^{100}$

By 1955, McLean had built a prospering trucking company. Since Interstate Commerce Commission (ICC) rules did not allow a person to control more than one cargo transport company, McLean sold his thriving trucking business on the chance that containerized cargo would be the wave of the future. He invented the steel-reinforced corner-post structure of the shipping container so that it could be lifted on and off the cargo ship and also be strong enough to stack one on top of another in the holds and on the deck of the vessel. To prove that this new system of cargo movement would work, McLean converted an oil tanker for the carriage of his new containers, and sent the newly named Ideal $X$ (See Figure 4) on its way from Newark, New Jersey

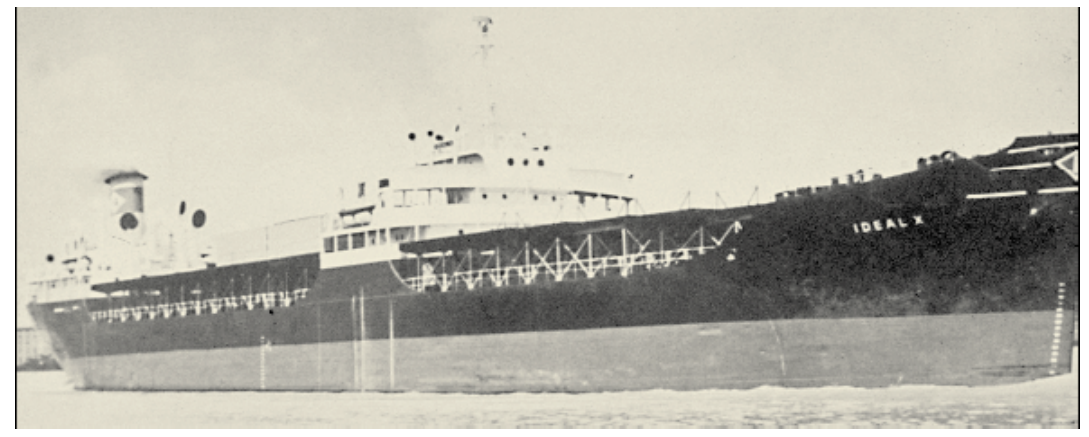

Figure 4

to Houston, Texas. When the cargo arrived undamaged and dry, the container revolution had begun. ${ }^{101}$

Several challenges to the spread of containerization arose after McLean proved it was a feasible and efficient method to transport cargo. Ports now needed ample space to

100 Anthony J. Mayo and Nitin Nohria, In Their Time: The Greatest Business Leaders of the Twentieth Century (Boston: Harvard Business School Press, 2005), 202-203.

101 Mayo, In Their Time, 204-205. 
store and organize containers before and after ship transport, and they needed equipment that would move the containers within the container yard and on and off the ships. However, as more ports took a chance on containerization and succeeded, this led other ports to modernize. In addition to adapting port cities to the new method of cargo transportation, labor realized that this new process of cargo handling would require fewer workers. The new technology would reduce manning on board ship and on the docks. ${ }^{102}$ Unlike containerization, another technological innovation of the 1950s, nuclear power, failed to take hold. On April 25, 1955, President Eisenhower announced that his program for the peaceful use of nuclear energy would include an atomic-powered

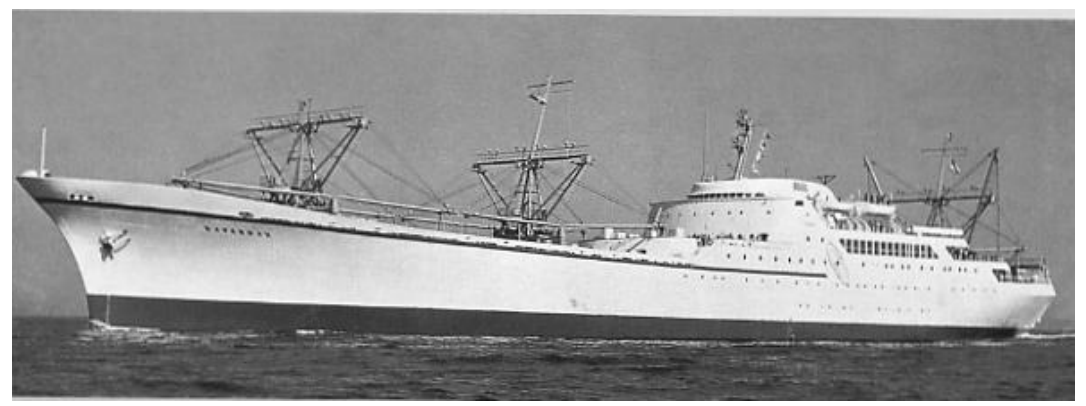

Figure 5 merchant ship. The building of this ship, the NS Savannah (See

Figure 5), was authorized on July 30,

1956, as a joint effort of the Atomic Energy Commission and the Maritime Administration (MARAD). ${ }^{103}$ Construction proceeded with New York Shipbuilding in charge of vessel fabrication while Babcock \& Wilcox Co. was responsible for developing the nuclear reactor. The ship was launched on July 21, 1959, and was ready for sea trials in early $1962 .{ }^{104}$

\footnotetext{
102 Mayo, In Their Time, 206.

103 Kuechle, Story of the Savannah, 12.

104 The Nuclear Ship "Savannah,” 2.
} 
The Savannah began as a showpiece, set up for combined passenger-cargo service, as an announcement to the world that the United States was using the atomic energy that proved so destructive in World War II for peaceful and prosperous purposes. The ship began service in 1962 and continued what was basically a good-will mission until August 20, 1965 when it entered the commercial cargo trade. After two years of commercial operation by American Export Isbrandtsen Line, MARAD judged the Savannah as too expensive to operate, and began the process for entering the ship into a lay-up status. The U.S. Congress questioned the wisdom of this action since so much time and money had been spent both on the ship and for crew training, and proposed "that operation of the nuclear merchant vessel Savannah is in the best interest of the United States of America and should continue.”105 Because of the overwhelming desire in Congress and in the maritime industry to keep the Savannah on the high seas, MARAD awarded a charter to First Atomic Ship Transport, Inc., a wholly-owned subsidiary of American Export Isbrandtsen Lines, which lasted until 1970 when the NS Savannah was laid up in Galveston, Texas. ${ }^{106}$

Nuclear power never panned out as a popular method of propulsion for United States-flag merchant ships. The Savannah was the first and only vessel of its type to be registered under the American flag. Japan and Germany also tried to operate nuclearpowered merchant ships, but did not enter this field on a large scale. ${ }^{107}$ Apprehension about environmental concerns of nuclear energy and damaging effects of accidental

\footnotetext{
105 The Nuclear Ship "Savannah,” 1.

106 “The Savannah is Stationed at Home Port in New Role,” New York Times, January 16, 1972, S25.

107 “Nuclear-powered Ships,” Unranium Information Center, Ltd., Briefing Paper 32, March 2005; available from http://www.uic.com.au/nip32.htm; Internet: accessed on 08 March 2006.
} 
release of nuclear radiation led to high insurance costs and the effort to ban nuclear plants and ships from populated areas. ${ }^{108}$ The extra cost of larger, technically trained crews when combined with insurance and other operating costs made the Savannah too expensive for MARAD to keep in operation under its allotted budget. MARAD determined that the Savannah had "operated in demonstration and experimental service from 1962 to 1970, realizing all objectives set for it,”109 and it moved on to research other types of propulsion such as the gas turbine. ${ }^{110}$

\section{Vietnam and the Continuing Deterioration of the U.S. Merchant Fleet}

In 1965, the United States again found itself fighting a war far from home, and once again troops needed a continuous flow of supplies. By the mid-1960s, the American war fleet, and thus the major part of the American fleet as a whole, was approaching twenty years of service. This was usually considered the useful life of a ship. Despite subsidies provided for in the Merchant Marine Act of 1936, not enough new construction took place to furnish sufficient replacement tonnage for wartime needs. Bulk carriers in the commercial fleet were also supplied from the pool of war-built ships. Ships built in the 1940s were modified in the 1960s to extend their service lives. U.S. shipping laws allowed shipowners to build midsections in foreign shipyards for these wartime ships. As long as the midsection was installed in the United States, the ship was eligible to register

108 See "A-Powered Ships Would Be Barred By Bill in Council,” New York Times, March 1, 1970, 86, announcing the introduction of legislation to the New York City council to bar nuclear-powered ships from New York Harbor.

${ }^{109}$ U.S. Department of Transportation, Maritime Administration, NS Savannah Decommissioning Update, Jan. 2006, 1; available from http://marad.dot.gov/Headlines/newsletters/Jan2006/January\%202006\%20Newsletter-Page\%202.pdf; Internet: accessed on 06 March 2006.

110 “The Savannah is Stationed at Home Port in New Role,” New York Times, January 16, 1972, S25. 
in the U.S. and carry cargos specifically reserved by the Jones Act and cabotage laws for American-flag ships. Shipowners operated these old vessels until they were no longer safe, and at the end of profitable government-sponsored voyages that were intended to bolster the fleet, many were sent to scrapyards overseas without being replaced by new ships.

Troops in the Vietnam conflict would be receiving their critical support from the same ships that supported their fathers in World War II. The Department of Defense worked closely with the Maritime Administration to activate vessels from the National Defense Reserve Fleet (NDRF) to help fulfill sealift needs in Vietnam with ships left over from World War II. ${ }^{111}$ Seamen who sailed on these ships felt the brunt of the deterioration brought on by heavy service in World War II followed by an extended idle period. A merchant seaman who received an award for his courage during an explosion in 1967 on board his ship, the Margarett Brown, had an unfavorable opinion of the American merchant marine. Alfred D. Tuck said that the Margarett Brown, built in 1946, was "one of the decrepit rust buckets that merchant sailors are forced to ship out on.”112 He stated that ships of the American merchant fleet were being "held together with baling wire," and he described an incident where "a sailor put his foot through the bottom of his lifeboat during a lifeboat drill." 113

Although several American shipping liners operated newer, more efficient ships, these ships were in regular commercial service. Sailing routes that were essential to American trade, liner companies operated on regular schedules with regular customers.

\footnotetext{
111 Vietnam-Shipping Policy Review, 08 February 1966, 3-6.

112 “Vietnam Merchant Vessels Called Unfit for Duty,” New York Times, November 26, 1967, 86.

113 “Vietnam Merchant Vessels Called Unfit for Duty,” New York Times, November 26, 1967, 86.
} 
When defense needs required that these ships be called to service in Vietnam, the routes left open were filled by foreign-flag ships. The liner companies then became concerned about their post-war operations and whether or not they would regain their previous service on their liner routes. ${ }^{114}$

Another problem was whether or not enough merchant seamen could be found to man the nation's ships during the Vietnam War. With the activation of so many NDRF ships, maritime unions faced the problem of providing seafarers for ships already in commercial service and for the more than 100 ships activated from the NDRF. To fulfill the increased manning demands, unions turned to retired members and trained seamen working in shoreside positions. ${ }^{115}$

In a message to Congress on October 23, 1969, President Richard Nixon addressed the problem of the dwindling American merchant fleet. His first sentence summed up the crisis: "The United States Merchant Marine - the fleet of commercial ships on which we rely for our economic strength in time of peace and our defense mobility in time of war - is in trouble." 116 He recognized this trouble as coming from both government and the maritime industry. Nixon challenged all parties to join in rebuilding the American merchant marine. He proposed several ways to restructure the subsidy provisions of the Merchant Marine Act of 1936 to reduce government expenditures while revitalizing the shipping industry. ${ }^{117}$

\footnotetext{
114 Vietnam-Shipping Policy Review, 08 March 1966, 103-120.

115 Vietnam-Shipping Policy Review, 10 March 1966, 3, 256.

116 U. S. Congress, House, Committee on Merchant Marine and Fisheries, Subcommittee on Merchant Marine, President's Maritime Program, Part 1, $91^{\text {st }}$ Cong., $1^{\text {st }}$ sess., 28 October 1969, 2.

117 President's Maritime Program, 2-6.
} 
Congress revised the provisions of the Merchant Marine Act of 1936 according to the President's proposals, adding amendments that have come to be known as the Merchant Marine Act of 1970. Although some ships were built as a result of Nixon's efforts, most notably the “San Clemente” class supertankers (See Figure 6), ${ }^{118}$ the program fell far short of revitalizing the fleet. In effect, it enabled subsidies to continue, but

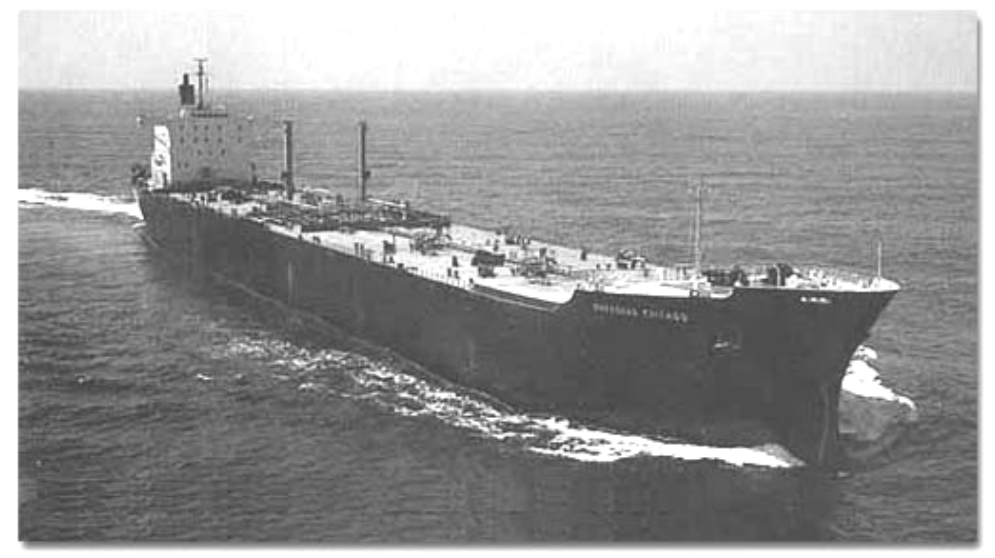

Figure 6 the cost of building a ship in the United States remained high.

Into the 1980s, the United States merchant fleet still contained World War IIvintage ships. While companies were building new types of vessels, such as container ships and bigger oil tankers, many ships used in the bulk cargo trades were those of the World War II era. The trend in this part of the industry was to repair and renovate the existing ships rather than build a new fleet. Preference cargos and coastwise trade in the United States was limited to American-flag ships that were built in the United States. These were lucrative trades if the owner could save money by using an existing ship without putting much money into maintenance and upkeep. If an old ship could be kept running, a shipowner would not have to face the high cost of building a new ship in a

118 Thirteen "San Clemente” class super tankers were built between 1974 and 1978, and two "San Clemente" class oil/bulk/ore (OBO) ships were built in 1973-1974 under the provisions of the Merchant Marine Act of 1970. They were named in honor of President Nixon's efforts to revitalize the American merchant marine. "Commercial Ship Portfolio: San Clemente Class Tanker," available from http://www.nassco.com/cdc/cportfolio/sanclem_enlg.html; Internet: accessed on 08 March 2006; "Commercial Ship Portfolio: San Clemente Class OBO," available from http://www.nassco.com/cdc/cportfolio/sanclemobo_enlg.html; Internet: accessed on 08 March 2006. 
U.S. yard. One example of the renovation and continued use of an aging World War IIbuilt ship, the Fort Mercer, has already been mentioned. Other ships during the early 1980s were not as lucky as the Fort Mercer, which made it to the scrap yard. Instead they went down while underway taking most if not all of their crews with them.

Hearings held on the converted war-era T-2 tanker, Marine Electric (See Figure 7), which sank off the coast of Virginia in February 1983, bared the basic problems. Of the

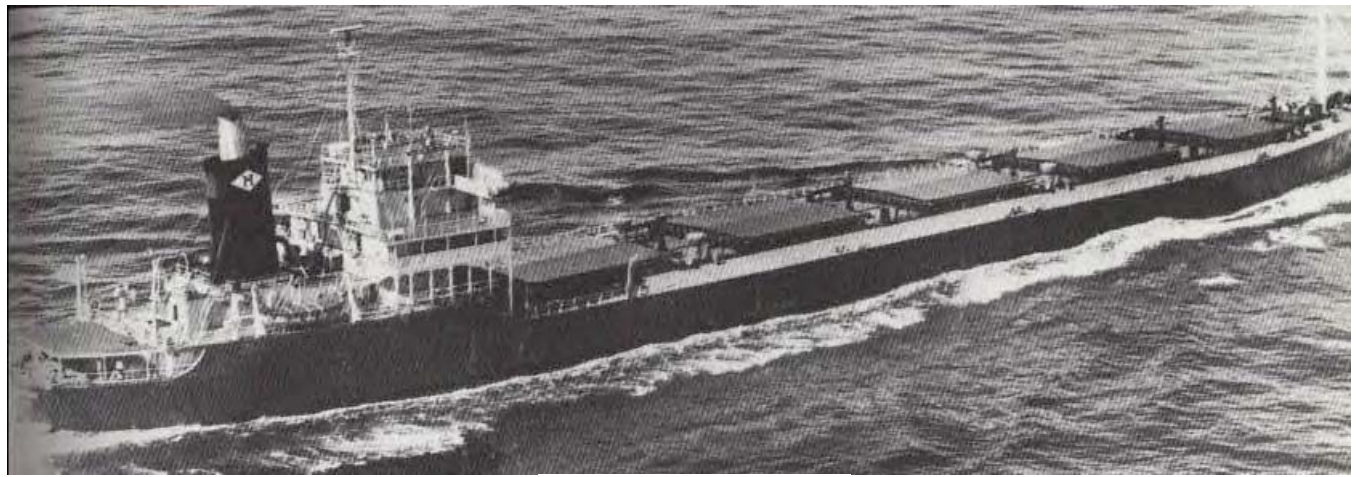

Figure 7

34-man crew, there were three survivors. When questioned by the U.S. Coast Guard, the three surviving crewmembers testified that the Marine Electric was in poor structural condition. The chief mate, Robert Cusick, gave the Coast Guard detailed descriptions of rotting steel on board the ship, particularly in the vessel's hatch covers. Cusick had made a diagram of the ship’s hatch covers in early January 1983, and submitted the list to the ship’s captain, indicating the areas that were in need of repair. Many steel repairs had already been made to the deck plating and hatch covers during the first part of 1982 with maritime contractors installing doubler plates on deck and cropping out and renewing sections of the steel plating in the ballast tanks. Cusick testified that he attempted to patch the holes in the hatch covers with a marine epoxy called "Red Hand,” but the repairs were not holding under the working conditions of the ship. ${ }^{119}$

119 Marine Casualty Report, SS Marine Electric, 43-44, 68-70. 
The Marine Electric was due for its required drydocking by April 15, 1983, so temporary repairs continued on certain sections of the deck plating. The April 15 date was an extension of the original drydocking requirement, granted by the Coast Guard after a December 1982 mid-term inspection performed by a Coast Guard marine inspector at Brayton Point, Massachusetts. Even though the inspector did not go forward of the deck house due to ongoing cargo operations, he recommended that his superiors grant a drydock extension. The captain and chief engineer agreed that the ship did not have any problems that could not wait until mid-April, and so on January 6, 1983, the Coast Guard granted the requested extension. From this point until the sinking, the crew performed temporary repairs to holes in the hatch covers and to the ship’s ballast tanks and hull in an attempt to keep the ship operating until the drydocking in April. ${ }^{120}$

The lead investigator, Captain Dominic Calicchio, exposed the issue of the deterioration of the American fleet and the lax inspections that allowed ships like the Marine Electric to continue operating. He and the other investigators in the Marine Electric case recommended an examination of the Coast Guard Commercial Vessel Safety Program for improvement of marine inspector qualifications. Further in reference to vessel inspections, Captain Calicchio found that even though many American Bureau of Shipping (ABS) inspectors were quite experienced in the maritime industry, since they maintained a close relationship with the shipping company, they were not impartial inspectors. ABS was the classification society used by most American shipping companies to certify their ships as seaworthy. It conducted periodic inspections and

${ }^{120}$ Marine Casualty Report, SS Marine Electric, 70-73. 
issued documentation necessary for a ship to legally sail. ABS was paid by the shipowner for its services.

In an attempt to make the shipping companies and captains more responsible, Captain Calicchio and his colleagues recommended that the Fleet Director of Marine Transport Lines and Captain James Farnham, the Marine Electric's permanent captain who was on leave when the ship was lost, be indicted in federal court for allowing the continued operation of the Marine Electric in an unseaworthy condition. ${ }^{121}$

The loss of the Marine Electric prompted an investigation by a reporter from the Philadelphia Inquirer, Robert Frump, in which the deteriorating condition of the U.S.flag merchant marine was brought to the attention of the public. ${ }^{122}$ After Cusick testified before the Coast Guard on February 17, 1983, Frump recounted his story in the February $18^{\text {th }}$ issue of the Philadelphia Inquirer. ${ }^{123}$ He then began a crusade against the aging ships of the merchant marine.

In a series published in the Inquirer at the beginning of May 1983, entitled "Death Ships,” Frump addressed the problems of the aging American merchant fleet. He argued that the American merchant marine had arrived at its current condition through the acquiescence of the U.S. government to lobbying pressures of the shipowners and labor unions for greater government protection and subsidies. He stated that all parties to the maritime issue, including the government, blamed international competition, with its use

121 Marine Casualty Report, SS Marine Electric, 120-123.

122 For a detailed description of Robert Frump's investigation of the Marine Electric incident and the deterioration of the American merchant fleet, see Robert Frump, Until the Sea Shall Free Them: Life, Death, and Survival in the Merchant Marine (New York: Doubleday, 2001).

123 “Survivor of Storm-Ravaged Vessel Tells of Ship’s Defects, Mate’s Deaths,” Philadelphia Inquirer, February 18, 1983, A01. 
of cheap foreign labor, for the decline of the maritime industry. Frump, however, alleged that government protection and subsidies had promoted the use of aging, deteriorating ships instead of the building of a new fleet. Without addressing the solution to these various maritime industry problems, Frump sympathized with the seamen who were forced to sail on deteriorating ships simply to remain employed, and sought to rid the fleet of ships like the Marine Electric. ${ }^{124}$

Many seamen were aware of the deteriorating condition of the ships they were sailing aboard during the 1980s. Most were also reluctant to report these deficiencies, because if the ship was taken out of service, all it meant to the seamen was unemployment. If the ship was not taken out of service, the owner could always find another seafarer to take the place of one who left the ship or who complained about its condition. New ships were not being constructed for the American fleet at a rate sufficient to replace the aging ships as they were taken out of service. When a ship was scrapped, there was no certainty of a job on board another. Some officers who ultimately sailed aboard the old ships on their last voyages hadn't sailed in over a year or were so broke that they couldn’t even afford their union dues. ${ }^{125}$

The plight of the industry in the early 1980s, as far as seamen were concerned, was summed up by the thoughts of one seaman at the Philadelphia hiring hall in May of 1983: “If the Marine Electric pulled in here tomorrow, I’d get on board. ... I've got a wife, two kids and a mortgage and I haven’t worked in six months.”126

\footnotetext{
124 Philadelphia Inquirer, May 1, 1983, A01, A23; May 2, 1983, A01; and May 3, 1983, A01.

125 Philadelphia Inquirer, May 1, 1983, A01.

${ }^{126}$ Philadelphia Inquirer, May 1, 1983, A01.
} 
In his "Death Ship” series, Frump mentioned another war-era ship that was lost earlier in the 1980s, the SS Poet. ${ }^{127}$ Early on the morning of October 24, 1980, the Poet left the port of Philadelphia loaded with bulk grain bound for Alexandria, Egypt. The last known communication with the ship was a ship to shore radio call from the third mate to his wife on the evening of October $24^{\text {th }}$. On November $3^{\text {rd }}$, when the owner had not heard from the ship since its departure message, it notified the Coast Guard that the Poet was missing. Despite five days of attempting to contact the Poet and an additional ten days of searching by aircraft and ship, no sign of the Poet was ever found and none of its crew was ever heard from again. ${ }^{128}$

The U.S. Coast Guard investigation uncovered that the Poet's intended track would have taken it through a severe storm on October 25-26. While the Coast Guard was unable to determine the cause of the loss, it noted the deterioration of the hatch cover for number 1 hold. Several repairs had been made to the hatch cover, but permanent repairs had not been completed. Investigators surmised that a complete structural failure of the hull may have occurred, which caused the vessel to sink quickly. This would account for the lack of any distress signal or debris. ${ }^{129}$

While the cause of the Poet's disappearance has never been determined, Frump may have added it to his exposé on "Death Ships” since it was built in 1944 as part of the World War II shipbuilding program. Similar to the Marine Electric and many other war-

127 Philadelphia Inquirer, May 1, 1983, A01.

128 U.S. Department of Transportation, U.S. Coast Guard. Marine Casualty Report, SS Poet: Disappearance in the Atlantic Ocean after Departure from Cape Henlopen, Delaware on 24 October 1980 with Loss of Life. U.S. Coast Guard Marine Board of Investigation Report and Commandant's Action, 12 April 1982.

129 Marine Casualty Report, SS Poet, 56-57. 
built ships, the Poet was modified in 1965 to carry bulk cargo. ${ }^{130}$ Also, the sister ship of the Poet, the SS Penny, was actively targeted by Frump as an example of an accident waiting to happen. ${ }^{131}$

The Penny was being run in a deteriorated condition by a company owned by Henry J. Bonnabel. Bonnabel, who also owned the ill-fated Poet, had interests in several old bulk ships that were running government cargoes overseas. Many of his ships were in a rusted and dilapidated condition, but government preference cargoes were allowed to be carried by these old ships since they were built in the United States and flew the American flag, even though the idea behind subsidies and cargo preference laws was to promote the building of new American ships. Frump's articles became an impediment to Bonnabel's previously unfettered operations since the Coast Guard was now in the spotlight for approving the sailing of ships that weren't making it to their next ports. The heightened awareness of the dangers of the old war-built ships after the Marine Electric incident led the Coast Guard to apply its safety regulations more strictly.

The Coast Guard in Tampa, Florida caught up with the Penny while it was docked in Tampa and performed an inspection prior to allowing it to sail. After a thorough examination, the Coast Guard pulled the vessel's Certificate of Inspection, a Coast Guard document required on board American ships in order to legally sail, and held the ship in Tampa until a long list of repairs was completed. ${ }^{132}$ Feeling the increased pressure of the more stringent Coast Guard inspections following the Marine Electric incident, in

${ }^{130}$ Marine Casualty Report, SS Poet, 7.

131 Philadelphia Inquirer, May 1, 1983, A01.

132 “Still One More Rusty Voyage before the SS Penny Can Rest,” Philadelphia Inquirer, October 23, 1983, A01. 
October 1985, Bonnabel requested documentation that would allow the Penny one last cargo overseas on its way to the scrap yard. After safety repairs were completed, the Penny set sail on its last trip on October 25 carrying a profitable government cargo on the way to the scrap yard. Bonnabel also disposed of some of his other old ships in the same lucrative manner. Since the Coast Guard was now requiring owners of the old ships to make expensive repairs in order to keep them running, numerous ships of the war-time fleet were laid up or scrapped. Thus, a program of government cargo preference meant to subsidize the maintenance of a strong American merchant fleet, led to profits for shipowners while, without building new ships, they sold their old ships for millions of dollars for scrap at the end of the government-sponsored voyages. ${ }^{133}$

\section{Is There Hope For The American Fleet?}

The American merchant marine was trapped in a downward spiral. Innovation in ship propulsion and cargo carrying and handling methods could not alone keep the industry at its post-World War II height. By the mid-1980s, then, American-flag ships and American seamen were disappearing at an alarming rate.

At times, labor union pressures did not end with the best results for seafarers. Conflicting goals and ideologies between the many unions representing American officers and seamen more often than not damaged labor's bargaining position with management. The failure of seamen to unite behind a common cause led to an inefficiency that made foreign-flag operations attractive to many shipowners. This animosity also allowed shipowners to shop for the best deal among the several unions.

133 “Slowly, Aging Ships Sail to the Scrap Yard,” Philadelphia Inquirer, February 13, 1984, A01. 
As the shipowners played one union against another, unions were forced to accept lower wages to win vessel contracts. ${ }^{134}$

As containerized cargo and automated engine rooms became more popular in the maritime industry, the number of ships needed for cargo transport decreased along with the number of seamen required to operate the ships. While modern ships did not require the same size crew as the older merchant ships, the American seamen’s unions fought to keep the shipboard manning scales the same on board both types of ship. The tension that this caused between labor and management could have been avoided if the older ships had been replaced with new ones, as was intended by the subsidies offered in the Merchant Marine Acts of 1936 and 1970. This would have kept the American merchant fleet strong, and labor would not have been as concerned about job loss among its members.

After the Marine Electric sank, resulting in the loss of most of its crew, the old ships that were keeping many seafarers employed were taken out of service. The Coast Guard, under public scrutiny after the loss of the Poet and the Marine Electric, could not afford to continue letting American seamen risk their lives on board these ships. Rather than conducting costly repairs on board ships that were 40 years old, the owners decided to go for one last lucrative government cargo as they sent their ships to the scrapyard. These ships would not be replaced by modern vessels under the American-flag.

Since the United States government actively supported the growth of flags of convenience, it was not averse to allowing its nation's merchant ships to migrate toward open registries. Several shipowners took this route to higher profits. The many benefits

${ }^{134}$ See “Officers Union Could Dominate Maritime Industry,” Journal of Commerce, September 15, 1993, Maritime, 8B; and "The History of Union Rivalries: 45 Years Later, AMO Keeps Cranking," Journal of Commerce, October 26, 1995, Maritime, 1B. 
of flag of convenience registries, coupled with the fact that the main registries in Liberia and Panama had close ties to the United States government, encouraged the flight of shipowners toward these liberal alternatives to the strict regulations and higher costs of the American flag. U.S. government policy as stated in the Merchant Marine Act of 1936 had been reduced to political rhetoric as government actions contradicted its words in the implementation of maritime policy.

As the Reagan administration entered its second term in office, Congress attempted again to reduce subsidies to the merchant marine by allowing U.S.-flag liners to enter into rate agreements with other international carriers. This act was the first piece of legislation to restate government maritime policy in words other than those used in the Merchant Marine Act of 1936. The focus in the 1984 act shifted from an emphasis on maintaining an American-flag merchant fleet to carry domestic and foreign water-borne commerce, as stated in the 1936 act, to the goal of encouraging more efficient international shipping with less U.S. government interference. The Shipping Act of 1984 addressed national security needs by promoting "the development of an economically sound and efficient United States-flag liner fleet....”135

While the Shipping Act of 1984 attempted to approach the needs of the U.S.-flag merchant fleet in a different manner, government maintenance of the same maritime policy from 1936 through 1984, without enacting measures to support its policy, had by 1984 caused considerable damage to the structure of the American merchant marine.

${ }^{135}$ Compilation of Maritime Laws, 365; 46 U.SC. App. 1701 (2004). 


\section{Chapter 4: Cooperation and Maritime Reform, 1984-2006}

Instead of encouraging the maintenance of a viable American-flag merchant marine, the subsidy system originally set up in the Merchant Marine Act of 1936 established limitations and rules which led to a steep decline in American tonnage. Budget cuts in the 1980s ended some maritime subsidies, and the Reagan administration proposed new legislation to remove government influence from the operation of U.S.-flag merchant ships. As the focus of American maritime policy shifted to the liner fleet, national security policy changed to meet the needs of the post-Cold War world. With the American-flag fleet continuing to shrink, shipowners, shippers, labor, and shipyards realized that as long as they argued amongst themselves, the federal government would not act to help them.

The Reagan administration's attempt to release merchant shipping from the trappings of subsidy regulations was accompanied by cuts in subsidy appropriations. The Shipping Act of 1984 allowed American-flag shipping companies to better associate with their foreign competition to stabilize shipping prices. While this provided some relief in the liner trades, it did not prevent the consequences of bad business decisions made by American shipping executives. Malcolm McLean would once again be in the spotlight of container shipping, but this time with negative results for the American-flag fleet.

When the Cold War ended in 1989, trouble in the Persian Gulf led to another massive sealift, again to fight a war far from home. Several small campaigns followed into the 1990s, and the government realized that it was increasingly relying on foreignflag shipping and government-owned ships to meet its sealift needs. Government ships operated by the Military Sealift Command and the Maritime Administration would 
become important for national security needs, but without a commercial fleet, experienced American seafarers would be harder to find.

The American merchant marine looked to the government to bolster the commercial fleet. Cooperation within the maritime industry drove this new effort toward maritime reform. Maritime unions and ship managers set aside their differences in the interest of maritime promotion. Seamen's unions ended decades of internal animosity. Government aid to shipyards allowed modernization of American facilities. The relaxing of tension within the industry opened the door for Congressmen who had been trying to pass maritime reform legislation to finally realize their goal. Efforts by Senators Ted Stevens, Daniel Inouye, Trent Lott, and John Breaux, and Representative Gerry Studds, all from states with maritime and shipyard constituents, led to the enactment of new legislation to revitalize the U.S.-flag fleet.

When the government took an active role in developing new legislation to aid the maritime industry and maritime parties worked together, changes were made. The Shipping Act of 1984, addition of new militarily useful ships to the government reserve fleets, and the Maritime Security Program offered new incentives to the American-flag merchant marine. When the parties within the maritime industry cooperated, Congress took positive steps toward maintaining an American-flag merchant fleet.

\section{Liner Shipping and the Shipping Act of 1984}

Containerization and the renovation of ports around the world to accommodate containerized cargo dominated the 1980s and 1990s. The size and capacity of container 
ships grew. (See Figure 8.) Ships with roll on/roll off (ro/ro) ${ }^{136}$ capacity (See Figure 9)

also came more into favor during this time period, especially due to their usefulness for military surge sealift operations (See Figure 10). ${ }^{137}$ Efficiency of moving cargo was eons ahead of where it was in the mid-twentieth century.

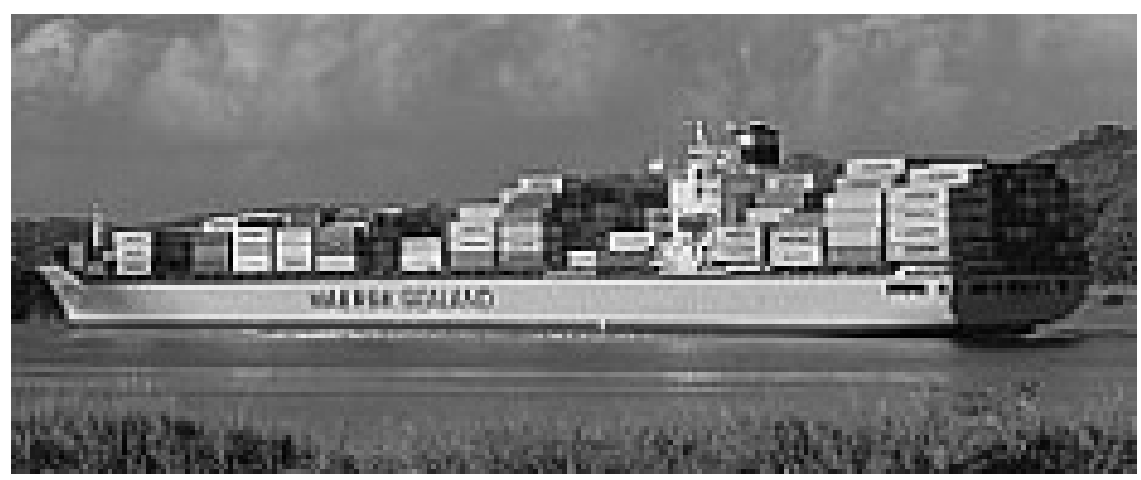

Figure 8

Ships that formerly needed weeks to load and discharge their cargoes were now in and out of port in hours. Congress again tried to amend the Merchant Marine Act of 1936 to entice American shipowners to register under the U.S. flag. While the attempt to amend the half-century old act failed, Congress also introduced new legislation which became the Shipping Act of 1984. The new law removed government restrictions on liner shipping companies that

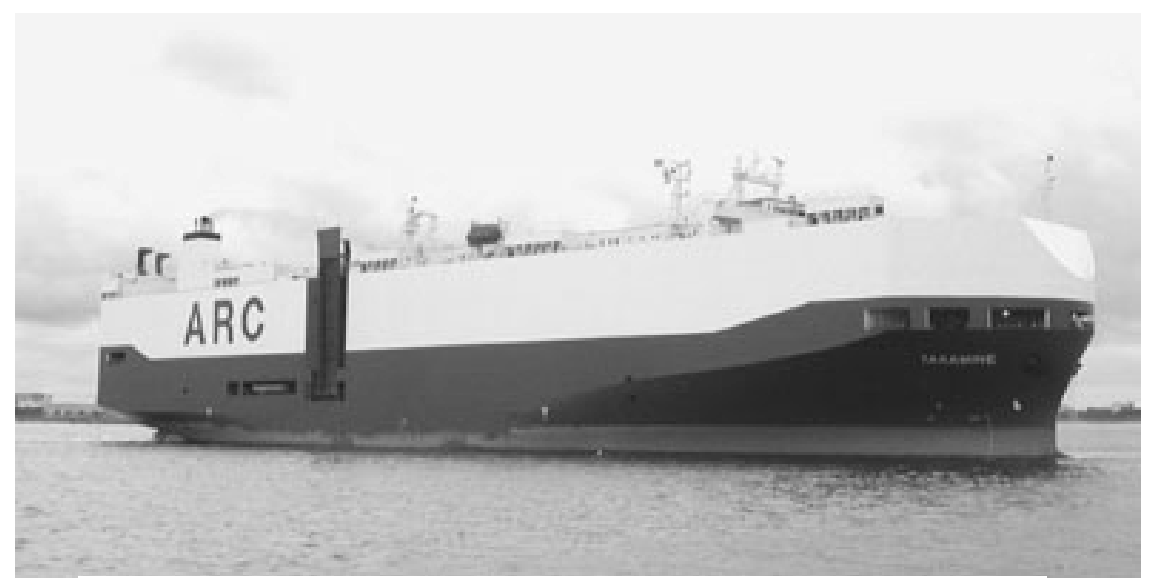

Figure 9

136 A ro/ro ship is one where the majority of the cargo is driven on and off the ship by way of cargo ramps; specialized ship used mainly for the transportation of vehicles. René de la Pedraja, $A$ Historical Dictionary of the U.S. Merchant Marine and Shipping Industry Since the Introduction of Steam (Westport: Greenwood Press, 1994), 508-509.

137 "Surge sealift" is the term used by the military to refer to the initial cargo needed for a military campaign that must reach the operation area quickly. See "Military Sealift Command; Sealift Program; Surge Project Office;” available from http://www.msc.navy.mil/pm5/default.asp?page=surge; Internet: accessed 29 June 2006. 
desired to enter into trade conferences with their foreign competitors. Nevertheless, American-flag shipping companies continued to collapse.

Congress debated two pieces of maritime reform legislation in 1983. Regulatory reform was split off from maritime promotional programs. Both bills proposed changes in the maritime industry that would remove government interference from business operations. Congress passed the Shipping Act of 1984, but the bill that was introduced as the Merchant Marine Act of 1983 was defeated.

Under their operating subsidy contracts with the government, shipowners were required to replace ships in their fleets once they

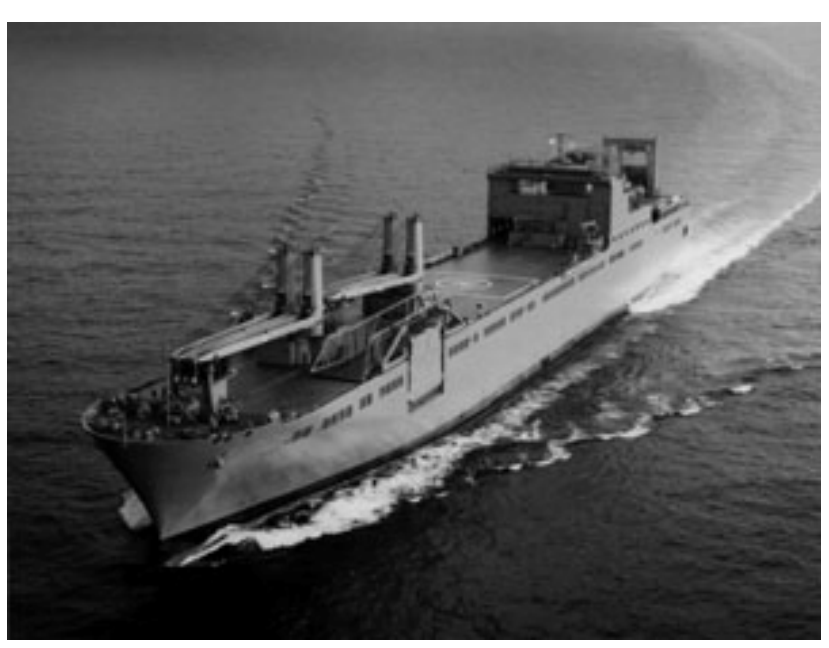

Figure 10 reached a certain age. American law compelled subsidized shipowners to build these new ships in the United States. Since building a ship in the United States cost about three times as much as building overseas, many shipowners could not afford to replace their aging ships without government construction subsidies. ${ }^{138}$ The Maritime Administrator, Admiral Harold Shear, expressed the Reagan administration's view on construction subsidies in hearings over the bill: “At present there is no intention of this Administration to continue with construction-differential subsidies.”139 Shipowners were then required to build new ships in the United States without government financial aid.

138 U. S. Congress, House, Committee on Merchant Marine and Fisheries, Subcommittee on Merchant Marine, Merchant Marine Act of 1983, 98 ${ }^{\text {th }}$ Cong., $1^{\text {st }}$ sess., 21 July 1983, 23, 28.

139 Merchant Marine Act of 1983, 21 July 1983, 29. 
The 1983 bill was an effort to amend the Merchant Marine Act of 1936 to allow shipowners to acquire ships from foreign sources. Foreign-built ships could be registered under the American flag and immediately carry preference cargoes. Congress had enacted a temporary measure in 1981 that allowed shipowners similar opportunities. As a result, several American liner companies placed shipbuilding orders in yards overseas before the stated deadline. The Merchant Marine Act of 1983 would have permanently removed the requirement for subsidized operators to build their ships in America. ${ }^{140}$ American shipyards were in as dire straights as the American-flag merchant marine and met these efforts with fierce opposition. Congressmen from states with shipbuilding interests such as Maine and Texas, as well as shipyards and shipbuilding labor unions vigorously fought passage of these amendments. The industry was still split due to shipyard dissention, but a major step toward cooperation in the rest of the industry happened at the hearings before the House subcommittee on Merchant Marine when shipboard labor unions and shipowners united in their efforts to pass the bill. ${ }^{141}$ Even so, the shipyard lobby proved its influence when the Merchant Marine Act of 1983 was defeated.

With the industry still split on promotional aid, the Reagan administration proposed a separate bill to achieve regulatory reform. Many new container and roll on/roll off (ro/ro) ships entered into the liner trades where they maintained punctual schedules and served well-defined routes. Antitrust laws hindered American-flag liner companies from full participation in international liner conferences. Even though

140 Merchant Marine Act of 1983, 21 July 1983, 23-28.

141 See Merchant Marine Act of 1983, 21 July 1983, 03 August 1983. 
Congressional debate showed concern over allowing select industries to bypass antitrust laws, ${ }^{142}$ Congress took an active step toward helping the struggling industry with new maritime legislation in the Shipping Act of 1984.

Shipping nations competing on the same route and offering the same types of carriage services often entered into liner conferences. A shipping liner that was a party to “any type of formal or informal agreement between ship owners that restrict[ed] competition” was a member of a liner conference. ${ }^{143}$ Liner conference manipulation of competition was not new to the twentieth century. After the invention and widening use of steamships in the nineteenth century allowed for scheduled departures and arrivals, British shipowners became the largest shipping liner operators. To organize their shipping trade, they began protecting and building their interests through conferences. ${ }^{144}$ Contemporary Americans were extremely averse to the monopolistic practices that were integral to shipping conference techniques, and in the Shipping Act of 1916 specifically outlawed anticompetitive tactics of liner conferences like deferred rebates ${ }^{145}$ and fighting

142 See U. S. Congress, Senate, Committee on the Judiciary, Shipping Act of $1983,98^{\text {th }}$ Cong., $1^{\text {st }}$ sess., 17 February 1983; U.S. Congress, House, Committee on the Judiciary, Subcommittee on Monopolies and Commercial Law, Shipping Act of 1983, 98 ${ }^{\text {th }}$ Cong., $1^{\text {st }}$ sess., 18 and 19 May 1983.

143 Alan W. Cafruny, "The Political Economy of International Shipping: Europe Versus America,” International Organization 39, no. 1 (Winter 1985): 94.

144 Cafruny, "Political Economy of International Shipping,” 95.

145 A “deferred rebate” under the Shipping Act of 1916 is defined as “a return of any portion of the freight money by a carrier to any shipper as a consideration for the giving of all or any portion of his shipments to the same or any other carrier, or for any other purpose, the payment of which is deferred beyond the completion of the service for which it is paid, and is made only if, during both the period for which computed and the period of deferment, the shipper has complied with the terms of the rebate agreement or arrangement.” U.S. Congress, $64^{\text {th }}$ Cong., $1^{\text {st }}$ sess., Chapter 451, Shipping Act of 1916, 07 September 1916, Sec. 14(1). 
ships. ${ }^{146}$ The 1916 act also created the United States Shipping Board and gave it authority to disapprove of agreements between carriers. ${ }^{147}$ Nevertheless, American companies continued into the 1960s using forbidden tools of the conference system to attract shippers and compete with other shipping lines. ${ }^{148}$

As U.S. government departments were reorganized throughout the twentieth century, "the administration of the regulatory provisions of the shipping laws" had shifted to the Federal Maritime Commission, created in 1961. ${ }^{149}$ The Department of Justice, however, maintained control over antitrust issues in the United States. Under pressure from the Department of Justice, the Federal Maritime Commission began to examine liner conferences more closely. American-flag shipping companies were not able to enter conferences with foreign shipowners if the provisions of the conference violated United States antitrust laws. The Shipping Act of 1984 provided an exemption from the antitrust laws for shipowners. To appease shippers who fought against conference price-control measures, the Shipping Act included provisions that would ban deferred rebates and fighting ships, and would allow a shipowner to change its prices on ten days' notice to other members of the conference. ${ }^{150}$

146 A "fighting ship" under the Shipping Act of 1916 is defined as "a vessel used in a particular trade by a carrier or group of carriers for the purpose of excluding, preventing, or reducing competition by driving another carrier out of said trade.” Shipping Act of 1916, Sec. 14(2).

147 Shipping Act of 1916, Secs. 3, 15.

148 Cafruny, "Political Economy of International Shipping," 97.

149 Federal Maritime Commission, “About Us,” available from http://www.fmc.gov/about/index.asp; Internet: accessed on 29 April 2006.

150 Cafruny, "Political Economy of International Shipping,” 101, 107; De la Pedraja, Historical Dictionary, 561-562; U. S. Department of Transportation, Maritime Administration. Compilation of Maritime Laws, 380-381; 46 App. U.S.C. 1709 (2004). 
While the Shipping Act of 1984 was the first positive step Congress made to assist the maritime industry in over a decade, relaxation of the antitrust laws in the shipping industry did not provide the boost the industry needed to recover from its woes. Some large liner companies did not participate in the conference system. Taiwan had recently launched the Evergreen Line which set its rates independent of conference participants. Evergreen proved a dangerous foe to the American-flag United States Lines, one of the largest container companies in the U.S.-flag fleet. Led by Malcolm McLean, U.S. Lines introduced a fleet of super-containerships into the market in the early 1980s in direct competition with Evergreen Lines.

Malcolm McLean entered the shipping business in the early 1950s after selling his trucking company. He began in 1955 by purchasing Waterman Steamship Company, which had emerged from World War II in good financial shape. From Waterman, McLean began his endeavor into containerized cargo, eventually splitting off one division and creating Sea-Land in $1960 .^{151}$

United States Lines originated as a government-owned shipping company that was created by the U.S. Shipping Board after World War I to operate passenger ship service in the North Atlantic. In the 1920s, the feeling in the United States was that business should be conducted by businessmen, not by the government. In 1926, the Shipping Board opened bidding for the purchase of United States Lines. After a period of uncertainty in the operation of U.S. Lines, two of the larger shipping companies in America, Dollar Line and International Mercantile Marine, formed a joint venture and bought United States Lines in 1931. Dollar Line was mainly a West Coast operation and

151 De La Pedraja, Rise and Decline of U.S. Merchant Shipping, 197-202. 
had been operating in the Pacific trade since the beginning of the twentieth century. International Mercantile Marine, on the other hand, was an Atlantic-based company that was created by J.P. Morgan in 1901-1902. McLean's and U.S. Line’s interests converged in 1977 when he purchased the line after selling his stock in Sea-Land. ${ }^{152}$

Before long, McLean endeavored on a bold effort to build a fleet of supercontainerships, called Econships, (See Figure 11) which were slower in speed than other new containerships in world trade, but would offer reduced shipping prices because of their size. U.S. Lines availed itself of the temporary opportunity in 1982 buy merchant ships on the

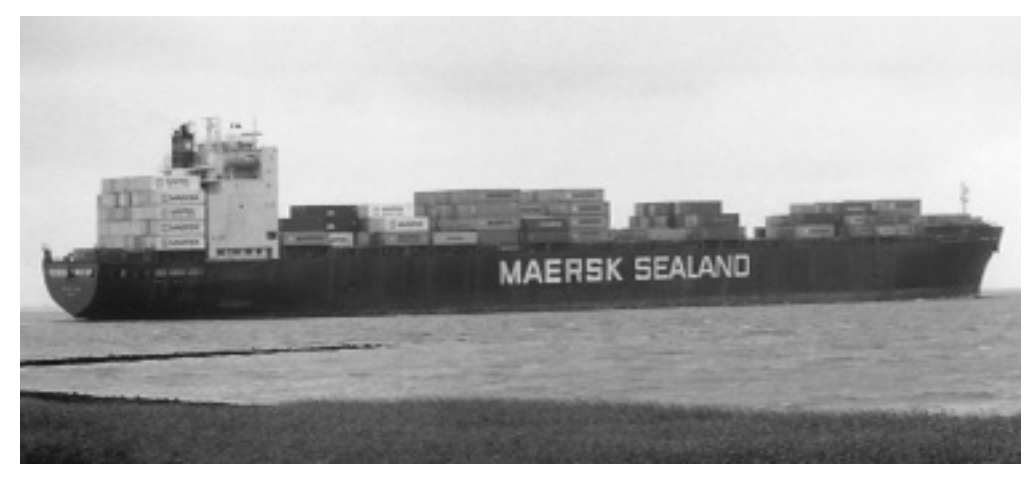

Figure 11

foreign market, and McLean ordered twelve Econships built in a shipyard in South Korea. ${ }^{153}$

McLean, however, misjudged many of the world economic factors he had counted on when planning his new fleet. Fuel prices, which had risen during the Carter administration, had dropped in the early 1980s. McLean’s slower ships then did not have as great an efficiency value over his faster competitors. McLean also overestimated the amount of cargo available in ports around the world that were large enough to accommodate the tremendous size of the new ships. As these disadvantages mounted,

${ }^{152}$ De La Pedraja, Rise and Decline of U.S. Merchant Shipping, 4, 20-22, 70, 73, 277.

153 De La Pedraja, Rise and Decline of U.S. Merchant Shipping, 278. 
United States Lines grew deeper in debt. ${ }^{154}$ In November 1986, McLean Industries declared Chapter 11 bankruptcy and halted both the worldwide and North Atlantic shipping services of United States Lines. ${ }^{155}$

With United States Lines gone, American President Lines and Sea-Land Services were the major container liners in the American-flag fleet. When Congress did not enact a new subsidy law for American-flag ships in the early 1990s, these liners requested permission from the Maritime Administration to re-flag part of their existing fleet, and also flag new ships under foreign registries. By 1995, these companies were operating ships under both the American flag and foreign flags. ${ }^{156}$

Maritime unions representing ships’ officers, the International Organization of Masters, Mates, \& Pilots and the Marine Engineers Beneficial Association District 1, stopped trying to keep these ships under the American flag. Instead, they bargained with the companies to retain American deck and engine officers from their unions on board while employing unlicensed seamen from foreign countries. ${ }^{157}$

\section{American-Flag Ships and National Security}

The Persian Gulf War in 1991 showed the United States that it would need to rely not only on its national merchant fleet, but also on foreign-flag ships to supply its troops. Much of the effort was getting the mass of equipment in place for the Desert Shield and

154 De La Pedraja, Rise and Decline of U.S. Merchant Shipping, 279-280.

155 “Bankruptcy Step Taken by McLean,” New York Times, November 25, 1986, Late City Final Edition, Section D, 1.

156 "Frustrated by Inaction, Unions Relent as US Carriers Hoist Foreign Flags, Lawsuits Exhausted, A Cooperative Spirit Emerges,” Journal of Commerce, August 7, 1995, Maritime, 5 B.

157 “Frustrated by Inaction,” Journal of Commerce, August 7, 1995, Maritime, 5B. 
Desert Storm operations. Relatively modern ports in the region, reliable communications links, a ready supply of fuel oil, and the short duration of the ground conflict reduced sealift capacity needed for a successful campaign. ${ }^{158}$ Nevertheless, more than fifteen million tons of support materials for the Persian Gulf campaign traveled overseas by water. The United States moreover conducted a six-month military build up prior to the start of the ground war. Foreign-flag ships contributed to the sealift effort to carry the equipment to the Persian Gulf area due to the lack of adequate U.S.-flag tonnage. Of the ships needed, “44 percent were foreign-flag ships, 41 percent were government-owned ships, and a mere 15 percent were privately owned U.S.-flag merchant ships.”159

After the war, Congressional concern over American sealift capacities led to hearings in the House Committee on Merchant Marine and Fisheries. ${ }^{160}$ The only proactive legislation enacted to aid the merchant marine since 1936 had been in 1970 and 1984. With the end of the Cold War, U.S. foreign policy objectives changed, and military preparedness shifted from global conflict to smaller, isolated campaigns. A reevaluation of merchant shipping capability was in order, yet George H.W. Bush administration priorities did not include such an agenda. Nevertheless, the existing maritime programs would have to fulfill sealift needs if the military was to succeed in its mission. The Military Sealift Command and Ready Reserve Force provided the majority of the shipping tonnage used in the Persian Gulf effort. However, foreign tonnage was

158 Wallace S. Reed, “U.S. Sealift and National Security,” in William A. Lovett, United States Shipping Policies and the World Market (Westport: Quorum Books, 1996), 262-263.

159 Reed, “U.S. Sealift and National Security,” 265-266, n39, quoting Robert W. Kesteloot, “Will Any Action Ever be Taken to Keep Our Merchant Marine Alive?” Sea Power 35.1 (1992): 58-65.

${ }^{160}$ See U. S. Congress, House, Committee on Merchant Marine and Fisheries, Subcommittee on Merchant Marine, Operation Desert Shield/Desert Storm Sealift Performance and Sealift Requirements, $102^{\text {nd }}$ Cong., ${ }^{\text {st }}$ sess., April/May 1991. 
still necessary and carried approximately twenty percent of the dry cargo required for the campaign. $^{161}$

The Military Sealift Command (MSC) controlled ship logistics for the Persian Gulf War. During the initial surge sealift into the area, MSC used seven fast sealift ships (See Figure 12) plus the ships on standby in the Maritime Prepositioning Force (MPF). The fast sealift ships could travel at speeds up to thirty knots and were specially configured for the carriage of military vehicles. ${ }^{162}$ These seven ships carried about ten percent of the dry cargo for the entire Persian Gulf campaign. ${ }^{163}$

The MPF, a collection of strategically located ships that remain fully loaded and wait to be called into action, also participated in the first

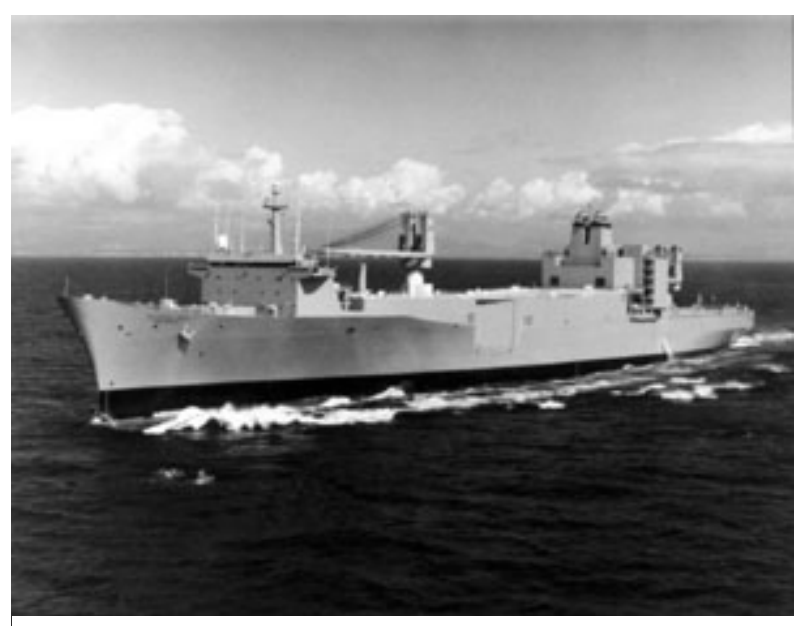

Figure 12 wave of supply to the Persian Gulf. After the MPF ships delivered their standby cargoes, they proceeded in the effort to keep the troops supplied throughout the operation. ${ }^{164}$

The Ready Reserve Force (RRF) contained the next supply of government ships, but unlike the MPF ships, the RRF ships were not on station, not fully loaded, and did not have a full crew on board. Once activated by the Maritime Administration, RRF ships

\footnotetext{
161 Operation Desert Shield/Desert Storm, 23 April 1991, 13.

162 “Military Sealift Command Ship Inventory, Sealift Ships,” available from
} http://www.msc.navy.mil/inventory/inventory.asp?var=PM5; Internet: accessed on 13 June 2006.

\footnotetext{
163 Operation Desert Shield/Desert Storm, 23 April 1991, 11.

164 Operation Desert Shield/Desert Storm, 23 April 1991, 11.
} 
were turned over to and operated by MSC. ${ }^{165}$ The United States faced many of the same problems it encountered in Vietnam during the sealift operation for the Persian Gulf. Ships in the RRF had deteriorated from an extended idle period and in many cases did not meet their designated breakout schedules due to machinery problems. Seafarers were also in short supply because of the reduction of the commercial merchant fleet, and unions were again forced to go to their retirement roles and to trained seamen working in shoreside positions. Before half of the RRF ships were underway, most of the pool of available seafarers had been exhausted. ${ }^{166}$ The government was also reluctant to pull liner ships off their normal trade routes since foreign ships could then slip into their spots, so it instead chartered foreign tonnage to move the military cargo. ${ }^{167}$

During the Persian Gulf War, the U.S. military discovered the benefits of maintaining adequate roll on/ roll off (ro/ro) capacity for emergency sealift actions, but it also realized that these ships were not well represented in the American-flag fleet. Ro/ro ships could be quickly loaded and quickly discharged and were ideal for carrying military vehicles. In the unstable atmosphere of military maneuvers, the faster the equipment arrived in the hands of the troops, the better. The Ready Reserve Force was modernized in the early 1990s to include a surge sealift force of ro/ro ships. The U.S. government built several Large Medium Speed Ro/Ro ships (LMSRs) and purchased others to fulfill the projected future needs of the military. ${ }^{168}$

\footnotetext{
165 “Military Sealift Command Ship Inventory, Sealift Ships,” available from http://www.msc.navy.mil/inventory/inventory.asp?var=PM5; Internet: accessed on 13 June 2006.

166 Reed, “U.S. Sealift and National Security,” 264.

${ }^{167}$ Operation Desert Shield/Desert Storm, 23 April 1991, 32-33.

168 Reed, “U.S. Sealift and National Security,” 270-271.
} 
A continuous maintenance program was also put in place for RRF ships needed for surge sealift operations. Small maintenance crews comprised of seafarers were placed on board these ships to alleviate some of the machinery problems faced during ship breakouts for Operation Desert Shield. These seafarers would also provide an experienced base for the crew called on to operate the ship when activated. ${ }^{169}$

After the Gulf War ended, the United States became involved in various United Nations and humanitarian missions in the 1990s throughout the world. U.S. efforts in Somalia, Haiti, Bosnia, and other trouble areas were aided by sealift missions undertaken by commercial ships chartered by the military and by RRF ships when necessary. ${ }^{170}$ The U.S. government realized, however, that the RRF was not all that the nation needed to carry out its current and projected sealift needs. A U.S.-flag commercial fleet was still required economically and for national security. The RRF was not structured to provide the nation with a trained pool of seafarers in all shipboard positions. Only a viable commercial fleet could provide the skilled people necessary to the program.

\section{The Maritime Security Program}

On the commercial side of the deep-sea American fleet, Congress passed the Maritime Security Program in 1996. The law provided assistance only for a limited time period. Before it expired, Congress amended and reauthorized the program in 2003. Four senators in particular put forth a tenacious effort to provide the maritime industry with much needed assistance. Senators Ted Stevens of Alaska, Daniel Inouye of Hawaii,

169 U.S. GAO, "Report to the Chairman, Subcommittee on Readiness, Committee on Armed Services, House of Representatives: Ready Reserve Force, Ship Readiness Has Improved but Other Concerns Remain,” November 1994, 16-17.

170 Reed, “U.S. Sealift and National Security,” 268-269. 
Trent Lott of Mississippi, and John Breaux of Louisiana kept a close eye on matters affecting the maritime industry as they attempted to pass new promotional legislation. Not only did they consider methods to improve maritime matters, but they also conducted oversight of requests of major U.S. liner companies to re-flag their ships elsewhere. The active efforts of Congressmen like these finally provided new laws to aid the struggling merchant marine.

After United States Lines went bankrupt, the two largest remaining U.S.-flag liner companies, Sea-Land and American President Lines (APL), sought government help to avoid that same fate. The Bush administration in 1990 attempted to reform the Operating Differential Subsidy program. But without agreement of all the parties of the maritime industry, the administration hesitated to act and no legislation was forthcoming. ${ }^{171}$ Next, the Clinton administration showed reluctance to support ongoing Congressional efforts at maritime reform. Rather than wait to see if yet another maritime assistance proposal would die in Congress, Sea-Land and APL petitioned the Maritime Administration (MARAD) in 1993 for permission to re-flag some of their current ships and to register new ships they were building under foreign flags. ${ }^{172}$

These requests alarmed Congress since, despite the lack of enthusiasm of the presidential administrations, it was currently in the process of developing maritime promotional reform. It did not want the largest American-flag shipping companies to bail out before it could realize its efforts. Representative Gerry Studds of Massachusetts, a strong proponent of maritime reform in the House, supported an amendment to a

171 Operation Desert Shield/Desert Storm, 23 April 1991, 16.

172 “Maritime Panel OKs Revised Reform Measure,” Journal of Commerce, July 30, 1993, Maritime, 8B. 
maritime budget bill that stalled the re-flagging efforts until progress could be made on new promotional legislation which was still in committee. ${ }^{173}$ In the Senate, the Subcommittee on Merchant Marine, attended by Senators Lott, Stevens, Inouye, and Breaux, held oversight hearings on what Breaux termed "the unfortunate decision by the two largest American shipping companies to begin reflagging their fleets under foreign flags.”174

While these Congressional efforts stalled American President Lines (APL) and Sea-Land, it did not stop them. APL was completing construction of six new containerships in foreign shipyards and wanted to register all of them under foreign flags. MARAD approved the request under the condition that APL register these ships under a flag which would give the U.S. effective control over the ships in time of emergency. APL would also have to wait for the outcome of reform legislation in Congress before it took action regarding re-flagging any of its existing fleet. ${ }^{175}$ APL readily accepted these conditions. ${ }^{176}$

The maritime reform legislation being debated in Congress since 1992 finally became law in 1996. The untiring efforts of Senators Stevens and Inouye during debate over the bill in the Senate overcame objections and proposed amendments by Senator

173 “House votes MARAD budget, ‘buys time’ on reflagging,” Journal of Commerce, July 30, 1993, Maritime, 5B.

${ }^{174}$ U. S. Congress, Senate, Committee on Commerce, Science, and Transportation, Oversight of the Foreign-Flagging Requests of American Shipping Companies, $103^{\text {rd }}$ Cong., $1^{\text {st }}$ sess., 05 August 1993, 1. Front, 1A.

175 "MARAD to allow APL to hoist foreign flags," Journal of Commerce, November 16, 1994, 1994, Front, 1A. 
Charles Grassley of Iowa. The act passed by a vote of 88 to $10 .{ }^{177}$ The Maritime Security Act added a new section to the Merchant Marine Act of 1936 that created a new subsidy structure for the American-flag fleet. The Maritime Security Program (MSP) offered a \$2.1 million dollar subsidy per ship to American-flag shipowners in return for making the ships and their intermodal facilities available to the government in time of national emergency. The program provided for a maximum of forty seven ships, and attracted the attention of several liner shipping companies. ${ }^{178}$

Shipyards did not oppose the MSP due to the revived Title XI loan guarantee program which "provides a Government guarantee on commercial loans for ships built in the United States.”179 The Title XI program contained provisions to assist shipyards in modernizing their yards and provided for loan guarantees of up to 87.5 percent of a 25year loan. ${ }^{180}$

The original MSP was set for a ten-year term with appropriations for funding the bill decided on an annual basis. ${ }^{181}$ Proponents of the MSP, determined not to let a program that was attracting and retaining ships in the American fleet lapse, began early to improve and present another Maritime Security Program before the current one ended. The result was the Maritime Security Act of 2003, which became effective, for the most part, on October 1, 2004. New provisions raised the maximum number of ships in the

177 Congressional Record, Senate, $104^{\text {th }}$ Cong., $2^{\text {nd }}$ sess., 24 September 1996.

178 “Carriers Start Queuing Up for Subsidies, Senate-Passed Bill on its Way to Clinton,” Journal of Commerce, September 26, 1996, $1 \mathrm{~A}$.

179 U. S. Congress, Senate, Committee on Commerce, Science, and Transportation, Subcommittee on Surface Transportation and Merchant Marine, Maritime Security Program, $104^{\text {th }}$ Cong., $1^{\text {st }}$ sess., 26 July 1995, 33.

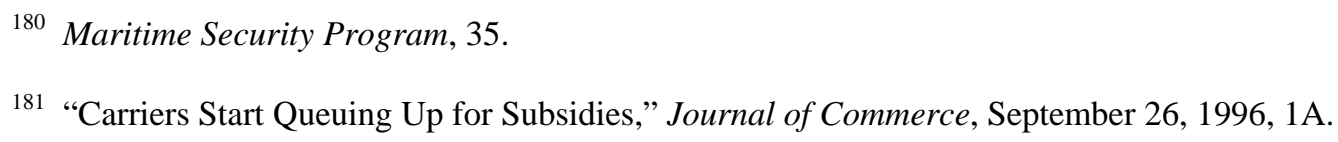


program to sixty, and allotted $\$ 2.6$ million dollars per ship with subsidy amounts to increase over the new ten-year period. The MSP allowed priority entry into the program by new tankers built in the U.S., thus trying to also give the shipbuilding industry a boost without requiring that all ships in the program be American built. Appropriations for the new program, however, remained subject to annual approval. ${ }^{182}$

One mounting concern with the implementation of the Maritime Security Program after its inception in 1996 was that more and more American-flag subsidized ships were being operated by United States subsidiaries of foreign corporations. After the MSP began in 1996, American President Lines, Lykes Lines, Farrell Lines, and Sea-Land, all major U.S. liner shipping companies, sold out to foreign interests. By 2003, "all but eight of the 47 MSP ships [were] run by U.S. intermediaries for overseas companies.”183 Opponents to allowing foreign ownership of many of the ships slotted for national security duties pressed for the problem to be resolved by changes made in 2003. But the program continued on with parent companies based overseas pulling the strings of U.S. subsidiaries operating MSP ships. ${ }^{184}$ With so few American-owned shipping companies that possessed ships which fit the requirements and needs of the MSP, United States national security increasingly depended on the loyalty of foreign companies.

\section{Where the Industry Stands Today}

Little evidence exists today of the overwhelming lead in world shipping that the United States possessed at the end of World War II. The bulk of the U.S.-flag fleet is

${ }^{182}$ Compilation of Maritime Laws, 93-112; 46 U.S.C. 53101-53111 (2004).

183 "Ready to Sail?; House Committee Unveils New Plan for US-flag Liner Subsidies,” Journal of Commerce, May 5, 2003, 12.

184 “Foreign Owners Tied to U.S. Fleet; Reliability during Crisis Questioned,” Boston Globe, March 12, 2006, $3^{\text {rd }}$ ed., National/Foreign, A1. 
comprised of the coastwise ships protected from foreign competition by the Jones Act, the ships of the Maritime Prepositioning Force and the Ready Reserve Force, and a few remaining containerships and ro/ro ships that operate commercially under subsidies provided in the Maritime Security Program.

The Shipping Act of 1984 freed the international shipping business from many U.S. antitrust law restrictions, but this was not enough to keep a viable liner fleet under the U.S.-flag. While American companies could now participate in foreign liner conferences, competition from liners outside the conferences took its toll. The over tonnage of some shipping routes also caused rate wars to attract the limited cargo available. The miscalculations of United States Lines and the flight of American President Lines and Sea-Land to foreign flags with their new vessels continued the decline of the American-flag merchant marine.

The hopes of today's American-flag deep-sea fleet lie with the modernization of the Ready Reserve Force and Military Sealift Command ships, and with the operation of the Maritime Security Program. The last strict test of maritime sealift capability is now in America's distant memory. Military operations in the last thirty years have been short term and have not required the continuous sealift that campaigns like World War II and Vietnam relied upon. Fortunately, in recent conflicts American troops have not noticeably suffered from the decreased tonnage capacity of the American-flag fleet. However, the nation still relied on foreign resources instead of autonomous action. When parts of the maritime industry began cooperating with each other, Congress finally passed new maritime legislation. Maritime unions began to set aside long histories of animosity and united to save the struggling industry. In 2001, the Seafarers 
International Union and the National Maritime Union, the two largest unlicensed seamen's unions in the nation, merged into one interest "by a 'nearly unanimous' tally.”185 The officers' unions followed suit when the American Maritime Officers (AMO) and the International Organization of Master Mates and Pilots (MMP) agreed in 2003 to greater cooperation between the unions. Also, the three largest officers' unions, AMO, MMP, and the Marine Engineers’ Beneficial Association (MEBA), all consented to a tripartite agreement not to underbid each other when pursuing government contracts. ${ }^{186}$ Finally, a recent alliance between the AMO and the Seafarers International Union of North America joined the interests of officers and seamen in the fight for a stronger American-flag fleet. ${ }^{187}$

While the maritime industry and Congress were uniting in some efforts at reviving the American-flag merchant marine, the U.S. government still hesitated when the issues became complicated. When it could please most of the people, Congress moved forward. However, when reluctance of parties in the industry surfaced or if American foreign policy would suffer, Congress backed up to the comfortable position of words without deeds. The ambivalence of the United States toward its merchant marine was summed up in a report by Kevin Baron of the Boston Globe when he referred to a 2002 hearing by the House Armed Services Committee regarding the concern over foreign ownership of the majority of the ships in the MSP. "The hearing ended with members of Congress expressing concern about the lack of US-owned ships $\underline{\text { but taking no }}$

185 “Maritime Unions Merge,” Journal of Commerce, June 5, 2001, available from JOC Online at http://web.lexis-nexis.com.www.libproxy.wvu.edu; Internet: accessed on 13 June 2006.

\footnotetext{
186 “AMO, MMP Reach Cooperative Agreement,” American Maritime Officer, August 2003, 1.

187 “AMO is New Member of SIUNA Family,” American Maritime Officer, December 2003, 1.
} 
action." 188 As long as the U.S. government sits on the fence between talk and action, cooperation by the parties comprising the maritime industry will be the only road toward recovery of a strong American-flag merchant marine.

188 “Foreign Owners,” Boston Globe, March 12, 2006, A1 (emphasis added). 


\section{Selected Bibliography}

\section{Primary Sources}

46 U.S.C. 53101-53111 (2004).

46 U.S.C. App. 1101 (2004).

46 U.SC. App. 1701 (2004).

50 U.S.C. App. 1735 (2004).

American Maritime Officer.

Boston Globe.

Congressional Record. Senate. $104^{\text {th }}$ Cong., $2^{\text {nd }}$ sess., 24 September 1996.

Economist.

“European Recovery and American Aid: A Report by the President's Committee on Foreign Aid (Parts One and Two),” (Washington, D.C., November 1947), B1-B3; available from http://www.trumanlibrary.org; Internet; accessed 16 November 2005.

Federal Maritime Commission. “About Us,” available from http://www.fmc.gov/about/index.asp; Internet: accessed on 29 April 2006.

Journal of Commerce.

Kimball, Warren F., ed. Churchill \& Roosevelt: The Complete Correspondence, I. Alliance Emerging, October 1933 - November 1942. Princeton: Princeton University Press, 1984.

Kimball, Warren F., ed. Churchill \& Roosevelt: The Complete Correspondence, II. Alliance Forged, November 1942 - February 1944. Princeton: Princeton University Press, 1984.

“Maritime Unions Merge," Journal of Commerce, June 5, 2001, available from JOC Online at http://web.lexis-nexis.com.www.libproxy.wvu.edu; Internet: accessed on 13 June 2006.

"Military Sealift Command Ship Inventory, Sealift Ships,” available from http://www.msc.navy.mil/inventory/inventory.asp?var=PM5; Internet: accessed on 13 June 2006. 
New York Times.

Philadelphia Inquirer.

"Radio Address of the President, Delivered from the White House," (December 29, 1940); available from http://www.fdrlibrary.marist.edu/122940.html; Internet: accessed on 10 November 2005.

Salter, Sir Arthur. Memoirs of a Public Servant. London: Faber and Faber, 1961.

“Top 20 Merchant Fleets of the World;” available from http://www.marad.dot.gov/MARAD_statistics/Flag-MFW-7-04.pdf; Internet: accessed on 20 June 2006.

"U.S.-Flag Merchant Fleet;” available from http://www.marad.dot.gov/MARAD_statistics/US-FLAG-HISTORY.pdf; Internet: accessed on 20 June 2006.

U.S. Coast Guard. Marine Board of Investigation; structural failure of tanker FORT MERCER off Cape Cod on 18 February 1952, with loss of life, 25 September 1952.

. Marine Board of Investigation; SS MARINE MERCHANT, O/N 245750; structural failure and ultimate sinking, 14 April 1961, Gulf of Maine, 1961.

. Marine Board of Investigation; structural failure of tanker PENDLETON off Cape Cod on 18 February 1952, with loss of life, 25 September 1952.

U.S. Congress. $74^{\text {th }}$ Cong., $2^{\text {nd }}$ sess., Ch. 858, Merchant Marine Act of 1936, 29 June 1936. 08 March 1946. $79^{\text {th }}$ Cong., $2^{\text {nd }}$ sess., Ch. 82, Merchant Ship Sales Act of 1946, Sec. 2, . $64^{\text {th }}$ Cong., $1^{\text {st }}$ sess., Shipping Act of 1916, 07 September 1916.

. House. Committee on the Judiciary, Subcommittee on Monopolies and Commercial Law, Shipping Act of 1983, 98 ${ }^{\text {th }}$ Cong., $1^{\text {st }}$ sess., 18 and 19 May 1983.

. House. Committee on Merchant Marine and Fisheries, Labor Management Problems of the American Merchant Marine. $84^{\text {th }}$ Cong., $1^{\text {st }}$ sess., 11 July 1955.

. House. Committee on Merchant Marine and Fisheries, Subcommittee on Merchant Marine, Merchant Marine Act of 1983, $98^{\text {th }}$ Cong., $1^{\text {st }}$ sess., July/August 1983. 
. House. Committee on Merchant Marine and Fisheries, Subcommittee on Merchant Marine, Operation Desert Shield/Desert Storm Sealift Performance and Sealift Requirements, $102^{\text {nd }}$ Cong., $1^{\text {st }}$ sess., April/May 1991.

. House. Committee on Merchant Marine and Fisheries, Subcommittee on Merchant Marine, President's Maritime Program, Part 1. 91 ${ }^{\text {st }}$ Cong., $1^{\text {st }}$ sess., 28 October 1969, 06 November 1969.

House. Committee on Merchant Marine and Fisheries, Subcommittee on Merchant Marine, Vietnam-Shipping Policy Review, Part $1.89^{\text {th }}$ Cong., $2^{\text {nd }}$ sess., February/March 1966.

Senate. Committee on Commerce, Subcommittee on Merchant Marine and Fisheries, The Nuclear Ship “Savannah.” 90 ${ }^{\text {th }}$ Congress, $1^{\text {st }}$ sess., June 12, 1967.

. Senate. Committee on Commerce, Subcommittee on Merchant Marine and Fisheries, U.S. Maritime Policy, 90 ${ }^{\text {th }}$ Cong., $1^{\text {st }}$ sess., 13 April 1967.

. Senate. Committee on Commerce, Science, and Transportation, Subcommittee on Surface Transportation and Merchant Marine, Maritime Security Program, 104 ${ }^{\text {th }}$ Cong., $1^{\text {st }}$ sess., 26 July 1995.

. Senate. Committee on Commerce, Science, and Transportation, Oversight of the Foreign-Flagging Requests of American Shipping Companies, $103^{\text {rd }}$ Cong., $1^{\text {st }}$ sess., 05 August 1993.

. Senate, Committee on the Judiciary, Shipping Act of 1983, $98^{\text {th }}$ Cong., $1^{\text {st }}$ sess., 17 February 1983.

U.S. Department of Commerce, Bureau of the Census, Statistical Abstracts of the United States, 1878 through 2005.

U. S. Department of State. Charter of the United Nations: Report to the President on the Results of the San Francisco Conference by the Chairman of the United States Delegation, the Secretary of State (June 26, 1945).

. Foreign Relations of the United States, 1940, Volume III. Washington, D. C.: U. S. Government Printing Office, 1958.

. Foreign Relations of the United States, 1941, Volume III. Washington, D. C.: U. S. Government Printing Office, 1959.

Foreign Relations of the United States, 1942, Volume I. Washington, D. C.: U. S. Government Printing Office, 1960. 
Foreign Relations of the United States, 1943, The Conferences at Washington and Quebec. Washington, D. C.: U. S. Government Printing Office, 1970.

. Foreign Relations of the United States, 1944, The Conference at Quebec. Washington, D. C.: U. S. Government Printing Office, 1972.

U. S. Department of Transportation, Maritime Administration, Compilation of Maritime Laws (Washington, D.C.: U.S. Government Printing Office, 2005).

. Maritime Administration, NS Savannah Decommissioning Update, Jan. 2006, 1; available from http://marad.dot.gov/Headlines/newsletters/Jan2006/January\%202006\%20Newsletter -Page\%202.pdf; Internet: accessed on 06 March 2006.

. Maritime Administration Vessel Status Card System; available from https://marad.dot.gov/marad_statistics/vsc/search.asp, Fort Mercer; Internet: accessed on 22 February 2006

. Maritime Administration Vessel Status Card System; available from https://marad.dot.gov/marad_statistics/vsc/search.asp, Pendleton; Internet: accessed on 22 February 2006.

. U.S. Coast Guard. Marine Casualty Report, SS Marine Electric, O.N. 245675, Capsizing and Sinking in the Atlantic Ocean on 12 February 1983 with Multiple Loss of Life. U.S. Coast Guard Marine Board of Investigation Report and Commandant's Action, 25 July 1984.

. U.S. Coast Guard. Marine Casualty Report, SS Poet: Disappearance in the Atlantic Ocean after Departure from Cape Henlopen, Delaware on 24 October 1980 with Loss of Life. U.S. Coast Guard Marine Board of Investigation Report and Commandant's Action, 12 April 1982.

U.S. GAO, "Report to the Chairman, Subcommittee on Readiness, Committee on Armed Services, House of Representatives: Ready Reserve Force, Ship Readiness Has Improved but Other Concerns Remain,” November 1994.

\section{Secondary Sources}

Adler, J. Hans, "British and American Shipping Policies: A Problem and a Proposal," Political Science Quarterly 59, no. 2 (June 1944): 193-219.

Batio, Christopher. Super Cargo Ships. Osceola: MBI Publishing Company, 2001.

Bauer, K. Jack. A Maritime History of the United States: The Role of America's Seas and Waterways. Columbia: University of South Carolina Press, 1988. 
Black, Henry Campbell. Black's Law Dictionary: Definitions of the Terms and Phrases of American and English Jurisprudence, Ancient and Modern. St. Paul: West Publishing Co., 1979.

Boczek, Boleslaw Adam. Flags of Convenience: An International Legal Study. Cambridge: Harvard University Press, 1962.

Butler,John A. Sailing on Friday: The Perilous Voyage of America's Merchant Marine. Washington: Brasswy’s, 1997.

Cafruny, Alan W. "The Political Economy of International Shipping: Europe Versus America,” International Organization 39, no. 1 (Winter 1985): 79-119.

Carlisle, Rodney. Sovereignty for Sale: The Origins and Evolution of the Panamanian and Liberian Flags of Convenience. Annapolis: Naval Institute Press, 1981.

Chapman, Paul K. Trouble on Board: The Plight of International Seafarers. Ithaca: ILR Press, 1992.

“Commercial Ship Portfolio: San Clemente Class Tanker,” available from http://www.nassco.com/cdc/cportfolio/sanclem_enlg.html; accessed on 08 March 2006.

“Commercial Ship Portfolio: San Clemente Class OBO,” available from http://www.nassco.com/cdc/cportfolio/sanclemobo_enlg.html; accessed on 08 March 2006.

De La Pedraja, René. A Historical Dictionary of the U.S. Merchant Marine and Shipping Industry Since the Introduction of Steam. Westport: Greenwood Press, 1994.

. The Rise \& Decline of U.S. Merchant Shipping in the Twentieth Century. New York: Twayne Publishers, 1992.

Dobson, Alan P. The Politics of the Anglo-American Economic Special Relationship 1940-1987. New York: St. Martin’s Press, 1988.

Dulles, Allen W. The Marshall Plan. Ed. Michael Wala. Providence: Berg Publishers, 1993.

Frump, Robert. Until the Sea Shall Free Them: Life, Death, and Survival in the Merchant Marine. New York: Doubleday, 2001.

Gibson, Andrew and Arthur Donovan. The Abandoned Ocean: A History of United States Maritime Policy. Columbia: University of South Carolina Press, 2000. 
Goldberg, Joseph P. The Maritime Story: A Study in Labor-Management Relations. Cambridge: Harvard University Press, 1958.

Hancock, W. K. and M. M. Gowing. British War Economy, 2d ed. London: Her Majesty’s Stationary Office, 1953.

Hoehling, A. A. The Fighting Liberty Ships: A Memoir. Annapolis: Naval Institute Press, 1996.

Hohman, Elmo Paul. History of American Merchant Seamen. Hamden: Shoe String Press, 1956.

"Ideal X;" available from http://www.portofhouston.com/pdf/pubaffairs/PHA90th\%20History\%20Brochure.pdf\#search='ideal\%20x\%20ship'; Internet: accessed on 17 May 2006.

Kuechle, David. The Story of the Savannah: An Episode in Maritime Labor-Management Relations. Cambridge: Harvard University Press, 1971.

Lane, Frederic C. Ships for Victory: A History of Shipbuilding under the U.S. Maritime Commission in World War II. Baltimore: Johns Hopkins University Press, 1951; Johns Hopkins Paperbacks edition, 2001.

Langewiesche, William. The Outlaw Sea: A World of Freedom, Chaos, and Crime. New York: North Point Press, 2004.

Lovett, William A. United States Shipping Policies and the World Market. Westport: Quorum Books, 1996.

“Maersk Virginia;” available from http://about.maersk.com/en/Fleet/Container/ContainerPanamax/SeriesDG/MaerskVir ginia.htm; and http://www.globalsecurity.org/military/systems/ship/maersk-g.htm; Internet: accessed on 22 June 2006.

“Marine Electric;”available from http://www.northernatlanticdive.com/2004_expeditions/marine_electric.jpg; Internet: accessed on 22 June 2006.

Mayo, Anthony J. and Nitin Nohria. In Their Time: The Greatest Business Leaders of the Twentieth Century. Boston: Harvard Business School Press, 2005.

McEwen, W. A. and A. H. Lewis. Encyclopedia of Nautical Knowledge. Centreville: Cornell Maritime Press, 1953. 
"Military Sealift Command; Sealift Program; Surge Project Office;” available from http://www.msc.navy.mil/pm5/default.asp?page=surge; Internet: accessed 29 June 2006.

Nelson, Bruce. Workers on the Waterfront: Seamen, Longshoremen, and Unionism in the 1930s. Urbana: University of Illinois Press, 1990.

“Nuclear-powered Ships,” Unranium Information Center, Ltd., Briefing Paper 32, March 2005; available from http://www.uic.com.au/nip32.htm; accessed on 08 March 2006.

Reynolds, David. The Creation of the Anglo-American Alliance 1937-41: A Study in Competitive Co-operation. Chapel Hill: University of North Carolina Press, 1981.

"Schenectady;" available from http://www.fiu.edu/ thompsop/liberty/photos/schenectady.jpg; Internet: accessed on 02 May 2006.

"Sea-Land Florida;" available from http://www.maerskline.com/link/?page=brochure\&path=/about_us/photo_gallery/ves sels_at_sea/Sealand_Florida_gallery; Internet: accessed on 22 June 2006.

Shashikumar, N., “Comparative Maritime Policies: A U.S. Dilemma,” Transportation Journal 34, no. 1 (Fall 1994): 32-38.

Smith, Kevin. Conflict over Convoys: Anglo-American Logistics Diplomacy in the Second World War. Cambridge: Cambridge University Press, 1996.

Tipper, C. F. The Brittle Fracture Story. Cambridge: Cambridge University Press, 1962.

"USNS Algol;" available from http://www.msc.navy.mil/inventory/ships.asp?ship=algol\&type=FastSealiftShip; Internet: accessed on 22 June 2006.

"USNS Bob Hope;" available from http://www.msc.navy.mil/inventory/ships.asp?ship=104\&type=LMSR; Internet: accessed on 22 June 2006.

Whitham, Charlie. Bitter Rehearsal: British and American Planning for a Post-War West Indies. Westport: Praeger, 2002.

Woods, Randall Bennett. A Changing of the Guard: Anglo-American Relations, 19411946. Chapel Hill: University of North Carolina Press, 1990.

Zeis, Paul Maxwell. American Shipping Policy. Princeton: Princeton University Press, 1938. 